Thu Feb 6 13:49:13 2020

Citations:

Bluebook 20th ed.

Amanda M. Rose, Calculating SEC Whistleblower Awards: A Theoretical Approach, 72 Vand. L. Rev. 2047 (2019).

ALWD 6th ed.

Amanda M. Rose, Calculating SEC Whistleblower Awards: A Theoretical Approach, 72 Vand. L. Rev. 2047 (2019).

APA 6th ed.

Rose, A. M. (2019). Calculating sec whistleblower awards: theoretical approach.

Vanderbilt Law Review, 72(6), 2047-2086.

Chicago 7th ed.

Amanda M. Rose, "Calculating SEC Whistleblower Awards: A Theoretical Approach,"

Vanderbilt Law Review 72, no. 6 (November 2019): 2047-2086

McGill Guide 9th ed.

Amanda M Rose, "Calculating SEC Whistleblower Awards: A Theoretical Approach" (2019) 72:6 Vand L Rev 2047.

MLA 8th ed.

Rose, Amanda M. "Calculating SEC Whistleblower Awards: A Theoretical Approach." Vanderbilt Law Review, vol. 72, no. 6, November 2019, p. 2047-2086. HeinOnline.

OSCOLA 4th ed.

Amanda M Rose, 'Calculating SEC Whistleblower Awards: A Theoretical Approach' (2019) 72 Vand L Rev 2047

Provided by:

Vanderbilt University Law School

-- Your use of this HeinOnline PDF indicates your acceptance of HeinOnline's Terms and Conditions of the license agreement available at https://heinonline.org/HOL/License

-- The search text of this PDF is generated from uncorrected OCR text.

-- To obtain permission to use this article beyond the scope of your license, please use: 


\title{
Calculating SEC Whistleblower Awards: A Theoretical Approach
}

\author{
Amanda M. Rose*
}

The Dodd-Frank Act provides that Securities and Exchange Commission ("SEC") whistleblower awards must equal not less than ten and not more than thirty percent of the monetary penalties collected in the action to which they relate; SEC Rule 21F- 6 provides criteria that the SEC may consider in determining the award percentage within the statutory bounds. When applying the Rule 21F-6 criteria, the SEC is required to think only in percentage terms, ignoring the dollar payout the award will actually yield. Last June, the SEC proposed to change this, at least in cases where the existing methodology would yield an award less than $\$ 2$ million or greater than $\$ 30$ million. The proposed revisions to Rule 21F-6 have garnered controversy and have not yet been implemented. Do they make sense? To begin to answer that question requires an understanding of the purpose of whistleblower awards and an evaluation of how well the existing award calculation methodology advances that purpose. This Article provides both. The analysis suggests that the controversial proposed amendments to Rule $21 F-6$ are warranted but incomplete.

I. The SEC's Whistleblower Program: A SHorT

PRIMER

II. Calculating Awards: Current Practice, Proposed REFORMS 2055

A. Current Methodology for Determining Award Amounts....

B. Data on Awards Granted. 2057

* Professor of Law, Vanderbilt University Law School. For helpful comments on prior drafts, I would like to thank Margaret Blair, Mike Delikat, Paul Edelman, Marc Gross, Robert Jackson, Morgan Ricks, William Shirey, Paige Skiba, Jordan Thomas, Randall Thomas, students in the Vanderbilt Law \& Business Seminar, and participants at the 25th Annual Symposium of the Institute for Law \& Economic Policy. 
C. Proposed Revisions to Rule 21F-6 2059

III. A THEORETICAL APPROACH TO AWARD CALCULATION ...... 2062

A. The Purpose of Whistleblower Awards ................ 2062

B. Evaluating the Percentage Method...................... 2068

IV. IMPLICATIONS FOR REFORM ........................................ 2074

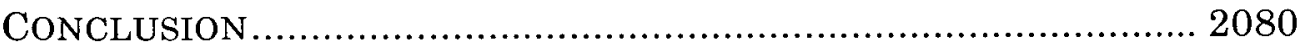

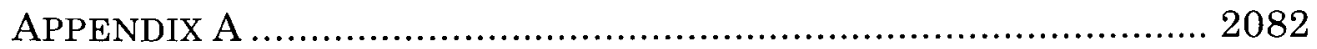

\section{INTRODUCTION}

After eight years in operation, the Securities and Exchange Commission's ("SEC") Whistleblower Program is undergoing retrospective review. Last summer, the SEC put out for public comment a lengthy release proposing a variety of amendments to the program's rules. ${ }^{1}$ Among the most controversial is a proposed amendment to Rule $21 \mathrm{~F}-6$, which sets forth the criteria for determining the amount of whistleblower awards. The Dodd-Frank Wall Street Reform and Consumer Protection Act, which created the whistleblower program, requires that the aggregate amount awarded to an eligible whistleblower or group of whistleblowers whose tip(s) led to a "covered action"-defined as an SEC action in which monetary sanctions in excess of $\$ 1$ million are ordered-equal not less than ten percent and not more than thirty percent of the monetary sanctions collected in the covered action and certain related actions. ${ }^{2}$ Within this range, the statute grants the SEC discretion to determine the award amount while setting forth certain nonexclusive criteria that the SEC shall take into consideration in the exercise of its discretion. ${ }^{3}$ Rule $21 \mathrm{~F}-6$, in turn, lists factors (including but not limited to those specified in the statute) that the SEC may consider "[i]n exercising its discretion to determine the appropriate award percentage." 4 These factors may cause the SEC to, in its discretion, "increase or decrease the award percentage." 5

As written, Rule 21F-6 requires that the SEC consider these criteria in determining the appropriate award percentage, seemingly without regard to the total dollars the award would yield for the whistleblower. SEC Chairman Jay Clayton has dubbed this "the

1. Whistleblower Program Rules, 83 Fed. Reg. 34702 (proposed July 20, 2018) (to be codified at 17 C.F.R. pts. 240 and 249 ).

2. $\quad 15$ U.S.C. $\S 78 u-6(b)(1)(2012)$.

3. $\quad 15$ U.S.C. $\S 78 \mathrm{u}-6(\mathrm{c})(1)$.

4. Securities Whistleblower Incentives and Protection, 17 C.F.R. $\S 240.21$ F-6 (2019).

5. Id. 
percentage formula" for determining whistleblower awards; 6 this article will refer to it as "the percentage method." The proposed revisions to Rule 21F-6 would free the SEC to consider the dollar amount of an award, but only in circumscribed ways and under limited circumstances: when an award determined using the percentage method would be very small in dollar terms (in which case an upward adjustment may be warranted) and, more controversially, when it would be extremely large in dollar terms (in which case a downward adjustment may be warranted). ${ }^{7}$ Commissioner Jackson and former Commissioner Stein have expressed concern that affording the SEC discretion to adjust downward large dollar awards may jeopardize the goals of the whistleblower program. ${ }^{8}$

A fundamental question is lurking in this debate: Why should the percentage method be the baseline for determining SEC whistleblower awards in the first place? Congress did not debate this question before imposing the requirement that whistleblower awards must equal between ten and thirty percent of the amount of monetary sanctions collected in a covered action. ${ }^{9}$ Nor does it appear that the SEC thought hard about this question when it decided to restrict itself to the percentage method as a way of determining what an award should be within the statutory ten to thirty percent range. The only statement concerning the methodology the SEC made when adopting Rule 21F-6 was that it was "[s]imilar to the approach used by the Department of Justice and Internal Revenue Service" ("IRS") in their payment of whistleblower awards under the False Claims Act and IRS Whistleblowers Program, respectively. ${ }^{10}$ The percentage method also

6. Jay Clayton, Chairman, Sec. \& Exch. Comm'n, Statement at Open Meeting on Amendments to the Commission's Whistleblower Program Rules (June 28, 2018), https://www.sec.gov/news/public-statement/statement-open-meeting-amendments-commissionswhistleblower-program-rules [https://perma.cc/HN4F-9N3B].

7. See infra Section II.C.

8. Robert J. Jackson, Jr., Comm'r, U.S. Sec. \& Exch. Comm'n, Statement on Proposed Rules Regarding SEC Whistleblower Program (June 28, 2018), https:/www.sec.gov/news/publicstatement/jackson-statement-whistleblowers-062818 [https://perma.cc/4YYM-6KZZ]; Kara M. Stein, Comm'r, U.S. Sec. \& Exch. Comm'n, Statement on Proposed Amendments to the Commission's Whistleblower Program Rules (June 28, 2018), https:/www.sec.gov/news/publicstatement/statement-stein-whistleblower-062818 [https://perma.cc/B7US-JHH2].

9. OFFICE OF INSPECTOR GEN., U.S. SEC. \& EXCH. COMM'N, REP. No. 511, Evaluation OF THE SEC'S WHISTLEBLOWER PROGRAM 22 (2013), https://www.sec.gov/files/511.pdf [https://perma.cc/5ZU8-273A] [hereinafter OIG REPORT] ("[W]histleblower award amounts were not a debated part of the Dodd-Frank Act.").

10. See Securities Whistleblower Incentives and Protections, Exchange Act Release No. 3464,545, 76 Fed. Reg. 34,300, 34,331 (June 13, 2011) [hereinafter WP Release]. Subject to various requirements, the former entitles those who bring a qui tam suit on behalf of the government to between fifteen and thirty percent of the proceeds of the action, 31 U.S.C. $\S 3730$ (d) (2012), and the latter entitles individuals who tip off the IRS about tax evaders to bounties between ten and 
resembles the preferred approach for determining the fee award paid to class action attorneys. But these analogies, while superficially appealing, do not necessarily support use of the percentage method in the context of SEC whistleblower awards.

This Article returns to first principles, articulating what an award calculation methodology should strive to achieve in light of the purpose of the whistleblower program and exploring how well the percentage method lives up to these expectations. It proceeds in four parts. Part I provides a brief overview of the SEC's whistleblower program. Part II explains in greater detail the current method employed by the SEC for determining the amount of whistleblower awards, reports data on the whistleblower awards that the SEC has granted to date, and describes the recently proposed amendments to Rule 21F-6 and the controversy they have provoked.

Section III.A then considers the purpose of the whistleblower program. The starting premise is that the whistleblower program is designed to encourage tips by altering the internal cost-benefit calculation a potential whistleblower might be expected to conduct when deciding whether to come forward. But encouraging tips is not an end in itself: it is a means to help the SEC in its deterrence mission. Not all tips will have this effect; to the contrary, some will impose more costs than benefits on the SEC. Thus, a more refined statement of the goal of the whistleblower program is to encourage desirable tips (that is, those that create more benefits than costs, and thus push the SEC closer to its goal of optimal deterrence) without simultaneously encouraging the submission of undesirable tips (namely, those that create net costs, and thus undermine the SEC's deterrence objective).

Section III.B evaluates how well the percentage method advances this purpose. It demonstrates that the percentage method laudably creates differential incentives to report based on tip desirability. All else equal, whistleblowers with relatively more desirable tips should expect higher awards than those with relatively less desirable tips, meaning they will find the benefits of reporting to exceed the costs more often. But the percentage method does not ensure that awards will not vastly exceed what is necessary to incentivize whistleblowers with desirable tips to come forward. Nor does it ensure that awards will not be so high as to encourage even undesirable tips or, conversely, that they will be high enough so as to encourage desirable tips. This will all depend on how the expected value of awards compares to the actual costs whistleblowers expect to bear by coming

thirty percent of the taxes the IRS collects as a result of the tip, 26 U.S.C. $\$ 7623$ (2012); Discovery of Liability and Enforcement of Title, 26 C.F.R. § 301.7623-4 (2019). 
forward. The percentage method, as currently applied, is insensitive to actual whistleblower costs.

Part IV explains that the proposed reforms to Rule 21F-6 would fix this problem in the subset of cases to which they would apply by inviting the SEC to consider the dollar amount of the award and to make adjustments depending on how the amount would affect whistleblower incentives. While the analysis suggests that the proposed reforms to Rule 21F-6 are warranted, it also suggests two additional reforms that could improve the functioning of the whistleblower program. First, tethering awards to the value of all penalties imposed in the covered action rather than simply to monetary penalties collected would better align whistleblowers' incentives to tip with the SEC's deterrence mission. Second, the SEC should be required to be more transparent about the percentages it awards and why. The SEC almost never publicly discloses the percentage it decides to award. This opacity is unnecessary and likely increases the risk discount that potential whistleblowers apply to expected awards when deciding whether the benefits of tipping outweigh the costs.

\section{The SEC's Whistleblower PRogram: A SHORT PRIMER}

The current framework for the SEC Whistleblower Program ("WP") is laid out in the Dodd-Frank Act ${ }^{11}$ and in SEC implementing rules adopted in 2011.12 The program entitles "whistleblowers"defined as individuals (not corporations or other entities) who provide the SEC with information about possible securities law violations pursuant to specified procedures ${ }^{13}$ - to a monetary award if they meet the following criteria. First, a whistleblower must have provided information to the SEC "voluntarily."14 Second, that information must have been "original."15 Third, the information must have "led to" a successful SEC enforcement action resulting in more than $\$ 1$ million in

11. 15 U.S.C. $\S 78 \mathrm{u}-6$ (2012).

12. See WP Release, supra note 10.

13. Securities Whistleblower Incentives and Protection, 17 C.F.R. $§ 240.21 F-2(a)(1)(2019)$.

14. This requires, inter alia, that the whistleblower submit the tip before the SEC requests information from the whistleblower related to the subject matter of the submission and that the whistleblower not be under a pre-existing legal duty to report the information to the SEC. See Amanda M. Rose, Better Bounty Hunting: How the SEC's New Whistleblower Program Changes the Securities Fraud Class Action Debate, 108 Nw. U. L. REv. 1235, 1261 (2014) (discussing the meaning of "voluntarily").

15. "Original information" is defined in the Dodd-Frank Act as information that is derived from a whistleblower's "independent knowledge or analysis" and "is not known to the [SEC] from any other source, unless the whistleblower is the original source of the information." 15 U.S.C. $\S 78 u-6(a)(3)$; see also Rose, supra note 14 at 1262-63 (discussing the meaning of "original information"). 
monetary sanctions (a so-called "covered action"). ${ }^{16}$ Finally, the whistleblower must not otherwise be ineligible for an award. ${ }^{17}$ Upon meeting these criteria and adhering to other procedural requirements for claiming an award, the whistleblower is entitled by statute to share in a whistleblower award of between ten and thirty percent of the sanctions collected in the covered action and in certain "related actions." 18

The SEC's Office of the Whistleblower ("OWB"), housed within the SEC's Division of Enforcement, is tasked with administering the WP. ${ }^{19}$ The OWB is currently staffed by a chief, two assistant directors, thirteen attorneys, four paralegals, and an administrative assistant. ${ }^{20}$ Among other things, the OWB maintains a website that provides information about the WP as well as links to the forms required to submit a tip (Form TCR) and apply for an award (Form WB-APP). ${ }^{21}$ The OWB ensures that any Form TCR it receives by mail or fax is inputted into the SEC's Tips, Complaints, and Referrals System (the "TCR System"), a centralized database for the "prioritization, assignment, and tracking of TCRs received from the public." 22

16. See Rose, supra note 14, at 1263-65 (discussing the meaning of "leading to success").

17. See id. at $1265-68$ (discussing ineligibility).

18. See id. at 1268-70. A "related action" exists if it is based upon the same original information that led to the covered action and is brought by the Attorney General of the United States, an "appropriate regulatory agency," an SRO, or a state Attorney General in a criminal case. 15 U.S.C. $\S 78$ u-6(a)(5); 17 C.F.R. § 240.21F-3(b)(1) (2019). "Appropriate regulatory agency means the [SEC], the Comptroller of the Currency, the Board of Governors of the Federal Reserve System, the Federal Deposit Insurance Corporation, the Office of Thrift Supervision, and any other agencies that may be defined as appropriate regulatory agencies under Section $3($ a)(34) of the Exchange Act (15 U.S.C. § 78c(a)(34) (2012)).” 17 C.F.R. § 240.21F-4(f) (2019). To receive an award based on a related action, the SEC must determine that the original information the whistleblower gave to the SEC also led to the successful enforcement of the related action under the same criteria used to evaluate awards for covered actions. 17 C.F.R. $\$ 240.21 \mathrm{~F}-3(\mathrm{~b})(2)$.

19. See 15 U.S.C. $\$ 78 \mathrm{u}-7$ (d) (discussing administration and enforcement).

20. U.S. SEC. \& EXCH. COMM'N, 2018 ANNUAL REPORT TO CONGRESS: WHISTLEBLOWER PROGRAM 6 (2018), https:/www.sec.gov/sec-2018-annual-report-whistleblower-program.pdf [https://perma.cc/M43U-VV77] [hereinafter WP 2018 REPORT].

21. See Office of the Whistleblower, U.S. SEC. \& EXCH. COMM'N, https:/www.sec.gov/whistleblower (last visited Oct. 6, 2019) [https://perma.cc/QBP2-P6UA].

22. Sarah N. Lynch \& Matthew Goldstein, Exclusive: SEC Builds New Tips Machine to Catch the Next Madoff, REUTERS (July 27, 2011) https://www.reuters.com/article/us-secinvestigations/exclusive-sec-builds-new-tips-machine-to-catch-the-next-madoff-

idUSTRE76Q2NY20110727 [https://perma.cc/NV8J-K3HF]; U.S. SEC. \& EXCH. COMM'N, ANNUAL REPORT ON THE DODD-FrANK WHISTLEBlOWER PROGRAM: FISCAL YeAR 20124 (2012), https:/www.sec.gov/files/annual-report-2012.pdf [https://perma.cc/W9T8-HBUQ] [hereinafter WP 2012 REPORT]. Whistleblowers also have the option to input their tip directly into the TCR System via an online version of Form TCR. For more information on the TCR System, see Ben Protess \& Azem Ahmed, With New Firepower, SEC Tracks Bigger Game, N.Y. TIMES: DEALBooK (May 21, 2012), https://dealbook.nytimes.com/2012/05/21/with-new-firepower-s-e-c-tracks-bigger-game/ [https://perma.cc/F9EC-374D]; Bruce Carton, Details Emerge on SEC Office of Market Intelligence, 
Once in the TCR System, a whistleblower's tip is triaged by the Enforcement Division's Office of Market Intelligence ("OMI"). ${ }^{23}$ The OMI evaluates each tip and assigns those identified as "sufficiently specific, timely, and credible to warrant the further allocation of [SEC] resources" to appropriate enforcement staff. ${ }^{24}$ As the SEC's investigation proceeds, the OWB serves as a liaison between the whistleblower (or his or her lawyer) and enforcement staff. It also works with enforcement staff to track enforcement cases involving whistleblowers "to assist in the documentation of the whistleblower's information and cooperation in anticipation of an eventual claim for award."25

After a final judgment is entered in a covered action, the OWB posts on its website a "Notice of Covered Action." ${ }^{26}$ Whistleblowers then have ninety days to file a claim for an award based on that covered action, using Form WB-APP. ${ }^{27}$ After the deadline for filing an appeal of the covered action has passed or, if an appeal has been filed, after the appeal has concluded, the SEC will evaluate all whistleblower claims that have been timely filed in connection with the action. ${ }^{28}$ It will determine whether any of the claimants meet the criteria for a whistleblower award and, if so, the appropriate percentage of collected sanctions to award them. ${ }^{29} \mathrm{~A}$ whistleblower can appeal the SEC's final decision denying his or her entitlement to an award, but an SEC decision regarding the amount of an award (including the allocation of an award as between multiple whistleblowers) is not appealable so long as the aggregate award falls within the required ten to thirty percent range. ${ }^{30}$

In addition to requiring the payment of whistleblower awards on the terms set forth above, the Dodd-Frank Act also contains provisions to protect SEC whistleblowers from workplace retaliation. Employers are prohibited from discriminating against whistleblowers in the terms and conditions of employment because they have provided information

SECURITIESDOCKET (Feb. 9, 2010), http://www.securitiesdocket.com/2010/02/09/details-emergeon-sec-office-of-market-intelligence/ [https://perma.cc/F3Z4-6LV4].

23. Protess \& Ahmed, supra note 22.

24. WP 2012 REPORT, supra note 22 , at 5. "When appropriate, tips that fall within the jurisdiction of another federal or state agency are forwarded to the [SEC] contact at that agency ...." Id.

25. Id. at 3 .

26. Securities Whistleblower Incentives and Protection, 17 C.F.R. $§ 240.21$ F-10(a) (2019).

27. 17 C.F.R. $\S 240.21$ F-10(a)-(b).

28. 17 C.F.R. $\$ 240.21$ F-10(d).

29. This involves multiple layers of review. See WP 2012 REPORT, supra note 22, at 7; OIG REPORT, supra note 9 , at 5 .

30. 17 C.F.R. $\S 240.21$ F-13(a) (2019). 
to the SEC or have assisted the SEC in an investigation or prosecution related to that information. ${ }^{31}$ The SEC can enforce this provision. ${ }^{32}$ Moreover, a whistleblower who believes his or her employer has violated this provision may sue for reinstatement, two times any back pay owed, and fees and costs. ${ }^{33}$ Unlike Sarbanes-Oxley's antiretaliation provision, which requires that claims be brought through the Department of Labor, ${ }^{34}$ the WP's antiretaliation provision allows whistleblowers to sue their employers directly in federal court. ${ }^{35}$ It also affords plaintiffs a more generous statute of limitations. ${ }^{36}$ To be entitled to this protection, whistleblowers need not qualify for a whistleblower award; it is sufficient that they possessed a "reasonable belief" that the information they provided to the SEC was related to a "possible securities law violation." 37

The SEC is also required to keep a whistleblower's identity confidential unless and until it is required to be disclosed to a defendant in a public proceeding or unless the SEC deems it necessary to share it with certain other authorities (in which case those authorities must keep it confidential) ${ }^{38} \mathrm{~A}$ whistleblower also has the option of remaining anonymous up to the point of receiving payment of a whistleblower award, at which time the whistleblower's identity must be disclosed to the SEC. ${ }^{39}$ Anonymous Form TCRs must be submitted through an attorney, however, and the whistleblower must provide that attorney with a declaration under penalty of perjury that the information on the form is true and correct. ${ }^{40}$ (Nonanonymous whistleblowers must make such a declaration directly on their Form TCRs. ${ }^{41}$ ) Finally, the WP makes it unlawful for anyone to take actions that impede an individual

31. The retaliation provision also protects individuals who have made disclosures that are required or protected under Sarbanes-Oxley and a variety of other laws. See 15 U.S.C. § 78u6(h)(1)(A) (2012) (explaining protections).

32. 17 C.F.R. $\S 240.21$ F-2(b)(2) (2019).

33. 15 U.S.C. $\S 78 \mathrm{u}-6(\mathrm{~h})(1)(\mathrm{C})$.

34. See OSHA Fact Sheet: Filing Whistleblower Complaints Under the Sarbanes-Oxley Act, OCCUPATIONAL SAFETY \& HEALTH ADMIN, http://www.osha.gov/Publications/osha-factsheet-soxact.pdf (last visited Oct. 6, 2019) [https://perma.cc/PL2X-FF2D] (employees must file complaint with OSHA).

35. 15 U.S.C. $\S 78 u-6(h)(1)(B)(i)$.

36. 15 U.S.C. $\$ 78 \mathrm{u}-6(\mathrm{~h})(1)(\mathrm{B})(\mathrm{iii})$. For a discussion of the problems with Sarbanes-Oxley's anti-retaliation provision, see Terry Morehead Dworkin, SOX and Whistleblowing, $105 \mathrm{MICH}$. L. REV. 1757, 1764-67 (2007). For a discussion of how the WP's anti-retaliation provision seeks to avoid these problems, see Rachel Beller, Note, Whistleblower Legislation of the East and West, 7 N.Y.U. J.L. \& BUS. 873, 914-15 (2011).

37. 17 C.F.R. $\S 240.21$ F-2(b)(1)(i).

38. 15 U.S.C. $\$ 78 u-6(h)(2) ; 17$ C.F.R. $\$ 240.21$ F-7(a) (2019).

39. 17 C.F.R. $\S \S 240.21$ F-7(b), 240.21F-9(c), 240.21F-10(c) (2019).

40. 15 U.S.C. $\S 78$ u-6(d)(2); 17 C.F.R. $\S \S 240.21$ F-7(b)(1), 240.21F-9(c).

41. 17 C.F.R. $\$ 240.21$ F-9(b). 
from becoming a whistleblower, including by threatening to enforce a confidentiality agreement. 42

\section{Calculating Awards: Current Practice, Proposed Reforms}

The SEC recently issued a lengthy release proposing numerous amendments to the rules governing the WP. Of particular interest for purposes of this Article are proposed amendments to Rule $21 \mathrm{~F}-6$, which governs the way in which the SEC determines the size of whistleblower awards. This Part describes the currently prescribed method for calculating whistleblower awards and the track record of awards granted using this methodology. It also explains the proposed modifications to Rule 21F-6.

\section{A. Current Methodology for Determining Award Amounts}

If one or more whistleblowers meet the eligibility criteria for an award and follow the required procedures for making a claim, the SEC is statutorily required to award them, in the aggregate, at least ten but not more than thirty percent of the monetary sanctions collected in the covered action. ${ }^{43}$ The SEC is also statutorily required to pay eligible whistleblowers an amount equal to ten to thirty percent of the monetary sanctions collected in "related actions," 44 if specified claims procedures are followed. ${ }^{45}$

The Dodd-Frank Act leaves the determination of the amount of an award, within the ten to thirty percent statutory bounds, to the SEC's discretion..$^{46}$ The Act provides, however, that in exercising this discretion the SEC shall take into consideration:

(I) [T] he significance of the information provided by the whistleblower to the success of the covered judicial or administrative action;

42. 17 C.F.R. $\S 240.21$ F-17. The SEC has taken steps to enforce this prohibition. See HomeStreet, Inc. and Darrell van Amen, Exchange Act Release No. 79844, 115 SEC Docket 5879, 2017 WL 218847 (Jan. 19, 2017) (finding HomeStreet in violation because it had taken steps to determine who the whistleblower was after receiving document requests from the SEC); BlueLinx Holdings, Inc., Exchange Act Release No. 78528, 114 SEC Docket 4599, 2016 WL 4363864 (Aug. 10, 2016) (finding BlueLinx in violation by use of a non-disclosure agreement which forced employees to either choose between identifying themselves to the company as whistleblowers or potentially losing their severance pay and benefits); KBR, Inc., Exchange Act Release No. 74619, 111 SEC Docket 917, 2015 WL 1456619 (Apr. 1, 2015) (requiring KBR to amend its confidentiality agreement so that it would not impede the purposes of the WP).

43. 15 U.S.C. $\$ 78 \mathrm{u}-6(\mathrm{~b})(1)$.

44. See sources cited supra note 18 and accompanying text (explaining "related actions").

45. See 17 C.F.R. $\$ 240.21$ F-11 (2019) (detailing these procedures).

46. 15 U.S.C. $\S 78 \mathrm{u}-6(\mathrm{c})(1)(\mathrm{A}) ; 17$ C.F.R. $\S 240.21$ F-5(a) (2019). 
(II) the degree of assistance provided by the whistleblower and any legal representative of the whistleblower in a covered judicial or administrative action;

(III) the programmatic interest of the [SEC] in deterring violations of the securities laws by making awards to whistleblowers who provide information that lead to the successful enforcement of such laws; and

(IV) such additional relevant factors as the [SEC] may establish by rule or regulation ... 47

The SEC is statutorily forbidden from "tak[ing] into consideration the balance of the [Investor Protection] Fund" ("IPF") when determining the size of a whistleblower award. ${ }^{48}$ The IPF was created by the Dodd-Frank Act to fund SEC whistleblower awards, as well as the SEC Inspector General's suggestion program, and has three replenishment sources. ${ }^{49}$ First, if its balance drops to $\$ 300$ million, the SEC must deposit into the IPF any monetary sanctions the SEC collects that are not paid into a fund for victims under $\S 308$ of the SarbanesOxley Act or otherwise distributed to victims (this money would normally go to the United States Treasury). ${ }^{50}$ Second, if the balance drops to $\$ 200$ million, the SEC must also deposit into the IPF any money in a section 308 fund that is not distributed to victims. ${ }^{51}$ And if there is not enough money in the IPF to pay a whistleblower award, the monetary sanction collected in the covered action on which the award is based shall be deposited into the IPF to cover the shortfall. ${ }^{52}$

Rule 21F- 6 further governs the SEC's exercise of discretion when determining whistleblower awards. The Rule lists factors that the SEC may consider "in relation to the unique facts and circumstances of each case," and provides that the SEC "may increase or decrease the award percentage based on its analysis of these factors." 53 In deciding whether to increase the amount of a whistleblower's award, the Rule requires the SEC to consider the three factors enumerated in the Dodd-Frank

47. 15 U.S.C. $\S 78 u-6(\mathrm{c})(1)(B)(i)$.

48. 15 U.S.C. $\S 78 \mathrm{u}-6(\mathrm{c})(1)(\mathrm{B})(\mathrm{ii})$.

49. 15 U.S.C. $\S 78 \mathrm{u}-6(\mathrm{~g})(1)-(2)$.

50. 15 U.S.C. $\S 78 \mathrm{u}-6(\mathrm{~g})(3)(\mathrm{A})(\mathrm{i})$.

51. 15 U.S.C. $\$ 78 \mathrm{u}-6(\mathrm{~g})(3)(\mathrm{A})(\mathrm{ii})$.

52. 15 U.S.C. $\S 78 \mathrm{u}-6(\mathrm{~g})(3)(\mathrm{B})$. The IPF is also entitled to keep income from investments made with its funds. 15 U.S.C. $\$ 78 \mathrm{u}-6(\mathrm{~g})(3)(\mathrm{A})(\mathrm{iii})$; see also 15 U.S.C. $\S 78 \mathrm{u}-6(\mathrm{~g})(4)$ (detailing the investments that may be made with IPF funds). The first infusion of funds into the IPF occurred in August 2010, when the SEC transferred to the fund the portion of a substantial monetary sanction it received that was not designated for payment to investors. See OIG REPORT, supra note 9 , at 26 (stating that in August 2010, "approximately $\$ 452$ million of non-exchange revenue ... was transferred to the fund from the SEC's disgorgement and penalties deposit fund").

53. If the SEC makes awards to multiple claimants, it "will determine an individual percentage award for each whistleblower, but in no event will the total amount awarded to all whistleblowers in the aggregate be less than ten percent or greater than thirty percent of the amount" collected. 17 C.F.R. $§ 240.21$ F-5(c) (2019). 
Act-the significance of the information provided to the success of the action, ${ }^{54}$ the degree of assistance provided by the whistleblower, ${ }^{55}$ and the SEC's "programmatic interest in deterring violations of the securities laws"56_as well as a fourth: the extent to which the whistleblower participated in an employer's internal compliance system. ${ }^{57}$ In deciding whether to decrease the amount of a whistleblower's award, the Rule requires the SEC to consider: (1) the "culpability or involvement of the whistleblower in matters associated" with the covered action or related action; 58 (2) whether the whistleblower unreasonably delayed in reporting the suspected securities violations; 59 and (3) "in cases where the whistleblower interacted with his or her entity's internal compliance or reporting system, whether the whistleblower undermined the integrity of such system."60

For each plus and minus factor, Rule $21 \mathrm{~F}-6$ provides from two to seven considerations that "the Commission may take into account, among other things" in evaluating the factor. ${ }^{61}$ No weight is assigned to these considerations or, for that matter, to the plus or minus factors themselves. Instead, the stated criteria in Rule $21 \mathrm{~F}-6$ are merely guidelines and do not create a rigid formula - "the determination of the appropriate percentage of a whistleblower award will involve a highly individualized review of the facts and circumstances surrounding each award." 62 The full text of Rule $21 \mathrm{~F}-6$ is set forth in Appendix A.

\section{B. Data on Awards Granted}

From the inception of the WP to the close of the SEC's 2018 fiscal year, the SEC issued whistleblower awards to fifty-nine individuals totaling over $\$ 326$ million. ${ }^{63}$ The majority of the awards have been for less than $\$ 2$ million, and the vast majority have been for less than $\$ 5$ million. ${ }^{64}$ But there have been a handful of substantially larger awards,

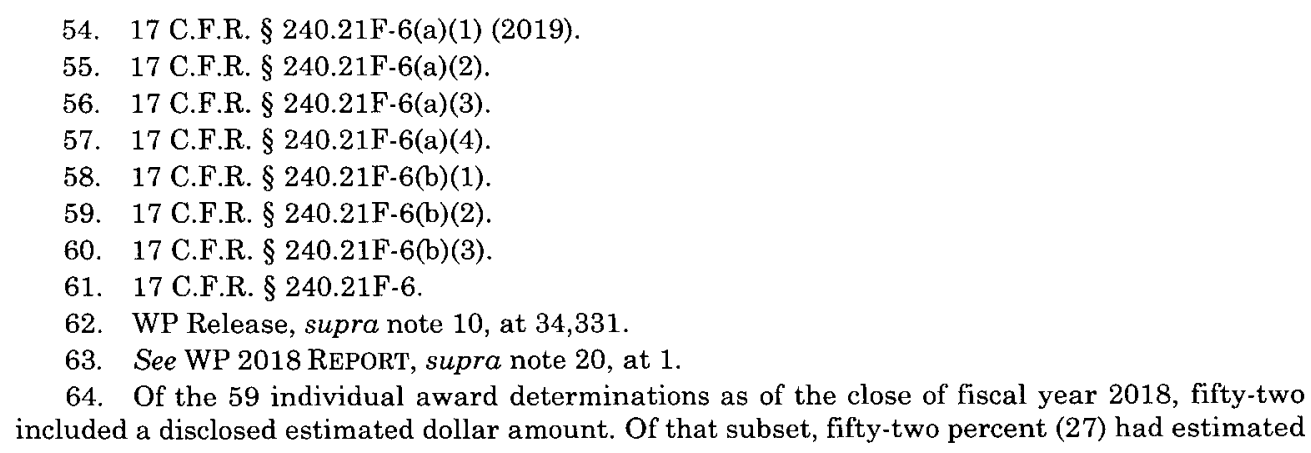

64. Of the 59 individual award determinations as of the close of fiscal year 2018, fifty-two included a disclosed estimated dollar amount. Of that subset, fifty-two percent (27) had estimated 
as demonstrated in Figure 1. The largest awards in the program's history were issued last year: in March $2018, \$ 83$ million was awarded in a covered action, with two whistleblowers splitting a $\$ 50$ million award and a third receiving a $\$ 33$ million award, and in September 2018, \$54 million was awarded in a covered action, with one whistleblower receiving a $\$ 39$ million award and another a $\$ 15$ million award. ${ }^{65}$ Prior to these awards, the biggest dollar award was issued to a single whistleblower in September 2014; it was estimated to pay out between $\$ 30$ and $\$ 35$ million. ${ }^{66}$ After the close of fiscal year 2018 , in March 2019, \$50 million was awarded in a covered action, with one whistleblower receiving a $\$ 37$ million award and another receiving a $\$ 13$ million award. 67

Little can be gleaned about the SEC's habits in setting award percentages from the heavily redacted award determination orders that are published on the SEC's website or from the press releases that often (but not always) accompany these orders. ${ }^{68} \mathrm{With}$ rare exceptions, these documents do not reveal information about the underlying offense that gave rise to the covered action. They tend to include only a rote recitation that the criteria in Rule $21 \mathrm{~F}-6$ were considered in setting the percentage. And, at least in recent years, these documents almost always omit the actual percentage awarded. According to my review, early in the program's history the SEC routinely disclosed the percentage awarded, but since 2015 , it has done so only once. ${ }^{69} \mathrm{By}$

award payouts of less than $\$ 2$ million and seventy-three percent (38) had estimated award payouts of less than $\$ 5$ million.

65. See Press Release, U.S. Sec. \& Exch. Comm'n, SEC Announces Its Largest-Ever Whistleblower Awards (March 19, 2018), https://www.sec.gov/news/press-release/2018-44 [https://perma.cc/8GCS-U797]; Press Release, U.S. Sec. \& Exch. Comm'n, SEC Awards More Than $\$ 54$ Million to Two Whistleblowers (Sept. 6, 2018), https://www.sec.gov/news/press-release/2018179 [https://perma.cc/S3NZ-VEHF].

66. See Press Release, U.S. Sec. \& Exch. Comm'n, SEC Announces Largest-Ever Whistleblower Award (Sept. 22, 2014), https://www.sec.gov/news/press-release/2014-206 [https://perma.cc/F2E5-UPZ9].

67. See Press Release, U.S. Sec. \& Exch. Comm'n, SEC Awards $\$ 50$ Million to Two Whistleblowers (March 26, 2019), https://www.sec.gov/news/press-release/2019-42 [https://perma.cc/6MDW-VT63].

68. In its annual report to Congress, the SEC provides in summary fashion some characteristics of successful whistleblowers. See, e.g., WP 2018 REPORT, supra note 20, at 16-17. The report does not, however, shed any light on the percentages awarded to whistleblowers or how the SEC has applied the Rule $21 \mathrm{~F}-6$ criteria.

69. Order Determining Whistleblower Award Claim, Release No. 80115 (Feb. 28, 2017), https://www.sec.gov/rules/other/2017/34-80115.pdf [https://perma.cc/6KZM-L6VZ] (reporting twenty percent award). This shift in practice coincides temporally with increasing average award payouts in dollar terms. Based on my review of individual awards that include disclosed estimates of payout amounts, from the program's inception through 2015 the mean individual award was approximately $\$ 3.4$ million (median approximately $\$ 419,000$ ). From 2016 to the close of fiscal year 2018 , the mean individual award more than doubled to approximately $\$ 7.4$ million (median approximately $\$ 3.5$ million). 
contrast, the SEC almost always announces the likely or actual dollar amount of the award. ${ }^{70}$

\section{Proposed Revisions to Rule 21F-6}

Rule $21 \mathrm{~F}-6$, in its existing form, requires the SEC to determine whistleblower awards using the percentage method without considering the total dollars that the percentage awarded would yield the whistleblower. So, in deciding that a twenty-five percent award is appropriate based on the factors laid out in the rule, the SEC is required to ignore that this would yield only $\$ 250,000$ in a covered action with $\$ 1$ million in monetary sanctions collected or a whopping $\$ 125$ million in a covered action with $\$ 500$ million in monetary sanctions collected. The proposed amendments to Rule $21 \mathrm{~F}-6$ would change this, allowing the SEC to consider dollar amounts in making award determinations, but only at the margins.

The first proposed change to the Rule would liberate the SEC to consider dollar amounts in cases involving very small awards. Specifically, if the monetary award that would result from application of the current criteria using the percentage method would lead to a payout of less than $\$ 2$ million (or any such greater amount that the SEC may periodically establish), the SEC would have the authority to adjust the award upward "to ensure that the total payout to the whistleblower more appropriately achieves the program's objectives of rewarding meritorious whistleblowers and sufficiently incentivizing future whistleblowers who might otherwise be concerned about the low dollar amount of a potential award." 11 The SEC "anticipate[s] that ... there would be a presumption in favor of some award enhancement, though the precise amount of the enhancement may vary from case to case depending on the unique facts and circumstances at issue." 72 Such upward modification is barred, however, if any of the current criteria for a downward adjustment apply or if the whistleblower was culpably involved in the misconduct giving rise to the covered action. ${ }^{73}$ In addition, any upward adjustment cannot raise the whistleblower's

70. Thirty-nine individual awards have been announced since 2016 . With respect to all but one, see id., the SEC disclosed the estimated dollar payout of the award but omitted the percentage of collected sanctions awarded.

71. Whistleblower Program Rules, 83 Fed. Reg. 34,702, 34,748 (July 20, 2018) (to be codified at 17 C.F.R. pts. 240,249 ).

72. Id. at 34,712 .

73. Id. at 34,748 . 
payout above $\$ 2$ million, nor may it cause the total amount awarded to all whistleblowers in the covered action to exceed thirty percent. ${ }^{74}$

The second proposed change to Rule 21F-6 would require the SEC to consider dollar amounts in certain cases involving potentially very large awards. If a whistleblower's original information led to one or more successful covered or related actions that, collectively, resulted in or will likely result in the collection of $\$ 100$ million or more in monetary sanctions (or any such higher amount that the SEC may periodically establish), the proposed amendments provide the SEC with additional instructions for fashioning the appropriate percentage.$^{75}$ First, in considering the existing Rule 21F-6 criteria for upward and downward adjustments, the SEC would be required to "consider[] the impact of the adjustments on both the award percentage and the approximate corresponding dollar amount of the award."76 Second, if the payout determined after applying those criteria is $\$ 30$ million or higher, the proposed amendments would require the SEC to "consider whether that amount exceeds what is reasonably necessary to reward the whistleblower and to incentivize similarly situated whistleblowers." "77 If it finds that it is, the Commission is instructed to "adjust the total payout... downward to an amount that it finds is sufficient to achieve those goals." 78 In no event, however, may the downward adjustment

yield a potential award payout (as assessed by the [SEC] at the time that it makes the award determination) below $\$ 30$ million, nor may any downward adjustment result in the total amount awarded to all meritorious whistleblowers, collectively, for each covered or related action, [falling below] 10 percent of the monetary sanctions collected in that action. ${ }^{79}$

In defense of this amendment to Rule 21F-6, the proposing release explains "there is a potential that as the payout to a whistleblower grows beyond the $\$ 30$ million floor, the marginal benefit

74. Id.

75. Id. at $34,748-79$.

76. Id. at 34,749 (emphasis added).

77. Id. In "determining whether a payout exceeds what is appropriate to achieve the program's objectives, the [SEC] would carefully assess the potential payout in relation to both any unusually detrimental circumstances that impact the whistleblower and the level of financial incentive that may be necessary to encourage future similarly situated whistleblowers to come forward." Id. at 34,715; see also id. at 34,715-16 (giving examples of unusually detrimental circumstances and financial incentive considerations).

78. Id. at 34,749 .

79. Id. at 34,714 . With respect to the amount of any downward adjustment, the proposing release imagines "a sliding scale that corresponds with the overall size of the potential award in dollar terms." Id. at 34,716. "In our view, this sliding-scale approach would make sense because the larger the dollar a mount of a payout away from the $\$ 30$ million floor, the greater the likelihood of diminishing marginal benefits to the program from each additional dollar paid to the whistleblower." Id. 
of each additional dollar paid may decrease to such an extent that, in terms of furthering the program's overall goals, the payout may be more than is reasonably necessary." 80 The proposing release also points to the preservation of the IPF as a basis for the amendment. The release explains that large awards "could substantially diminish the IPF, requiring the [SEC] to direct more funds to replenish the IPF rather than making that money available to the United States Treasury, where they could be used for other important public purposes." 81 The amendment "would help ensure that the [IPF] that Congress has established to pay meritorious whistleblowers is used in a manner that effectively and appropriately leverages the IPF to further the Commission's law enforcement objectives." 82

If past is prologue, the package of amendments to Rule $21 \mathrm{~F}-6$ would benefit a greater number of whistleblowers than they would disadvantage, given that there have been many more awards of less than $\$ 2$ million than there have been awards of $\$ 30$ million or more (by a margin of nine to one). ${ }^{83}$ But critics contend that the SEC should only be allowed to consider dollar amounts as a basis for increasing awards of less than $\$ 2$ million, not decreasing those in excess of $\$ 30$ million. This reflects a preference for higher whistleblower awards in general, and also more certain ones, in order to give whistleblowers strong incentives to come forward despite the risks they may face. SEC Commissioner Robert Jackson, for example, has argued that allowing the SEC to deviate from the percentage method to reduce very large awards could deter risk-averse whistleblowers from coming forward by making award amounts less predictable. ${ }^{84}$ Former SEC Commissioner Kara Stein has also expressed concern that allowing the SEC to deviate from the percentage method to reduce a large award could be "used as a means to weaken the Whistleblower Program." 85 The National

80. Id. at 34,714 . In the SEC's judgment, " $\$ 30$ million represents a reasonable line at which to draw the floor." Id. The release supports this judgment by pointing out that an individual who received $\$ 30$ million, even after taxes, would "find himself or herself in the range of the top 99.5 percentile to 99.9 percentile of the U.S. population by net worth" and, if invested modestly, could produce "a reasonable lifetime income stream for most potential whistleblowers." Id. at 34,715.

81. Id. at 34,704 .

82. Id. The large whistleblower awards issued in March 2018 caused the balance of the IPF to drop below the $\$ 300$ million threshold that triggers the statutory replenishment mechanism for the first time since the IPF's initial funding. Id. at 34,704, 37,715.

83. Based on my review of awards with estimated payouts disclosed as of the end of FY2018, the SEC has granted 27 individual awards estimated to payout less than $\$ 2$ million and 3 individual awards estimated to payout $\$ 30$ million or more.

84. Jackson, supra note 8.

85. Stein, supra note 8. 
Whistleblower Legal Defense \& Education Fund has also spoken out against this proposed amendment. ${ }^{86}$

\section{A THEORETICAL APPROACH TO AWARD CALCULATION}

Lurking behind the debate over the desirability of the proposed amendments to Rule $21 \mathrm{~F}-6$ is a more fundamental question: Why should the percentage method be the primary method for determining SEC whistleblower awards anyway, as opposed to some other methodology? Only once we understand the function the percentage method serves can we intelligently assess whether the SEC's proposed rule revisions are desirable.

\section{A. The Purpose of Whistleblower Awards}

We must begin with the purpose of whistleblower awards. Competing methodologies for computing awards must, after all, be evaluated based on how well they further that purpose. This Article assumes that the purpose of whistleblower awards is to incentivize individuals to submit tips to the SEC, with the ultimate goal of more efficiently deterring securities law violations. That the award program is meant to incentivize whistleblowers is supported by the very title of the statutory provision giving birth to it ("Securities Whistleblower Incentives and Protection"), 87 is consistent with the manner in which the SEC has framed and discussed whistleblower awards, ${ }^{88}$ and is the

86. Proposed SEC Rule Will Hurt Whistleblower Program, NAT'L WHISTLEBLOWER LEGAL DEF. \& EDUC. FUND (July 5, 2018), https://www.whistleblowersblog.org/2018/07/articles/doddfrank-whistleblowers/proposed-sec-whistleblower-rule/ [https://perma.cc/DW4A-5FCP].

87. 15 U.S.C. $\S 78 \mathrm{u}-6$ (2012) (emphasis added).

88. See, e.g., Press Release, U.S. Sec .\& Exch. Comm’n, SEC Issues \$4 Million Whistleblower Award (Sept. 20, 2016), https://www.sec.gov/news/pressrelease/2016-188.html [https://perma.cc/KY96-4Q97] (quoting Jane Norberg, Acting Chief of the SEC's Office of the Whistleblower, as stating that the WP "continues to incentivize whistleblowers to come forward with solid information that helps us bring violators to justice before more wrongdoing can occur"); Luis A. Aguilar, Comm'r, U.S. Sec. \& Exch. Comm'n, Speech by SEC Commissioner: Incentivizing Whistleblowers to Bring Fraud to Light (May 25, 2011), https:/www.sec.gov/news/speech/2011/spch052511laa-item2.htm [https://perma.cc/JD6S-DC28] (stating that the "goal of the whistleblower program is to create a system that incentivizes individuals to come forward with high quality information to help the Commission expose fraud"); Mary L. Schapiro, Chairman, U.S. Sec. \& Exch. Comm'n, Speech by SEC Chairman: Opening Statement at SEC Open Meeting: Item 2 - Whistleblower Program (May 25, 2011), https:/www.sec.gov/news/speech/2011/spch052511mls-item2.htm [https://perma.cc/J7Q3-PVEC] (explaining that the rules governing the WP were drafted to "incentivize those close to a fraud to come forward and provide information to the Commission"). 
most logical basis for the government to provide financial awards to whistleblowers. ${ }^{89}$

More precisely, I assume that the promise of a whistleblower award is designed to alter the internal cost-benefit calculation a potential whistleblower engages in when deciding whether to report wrongdoing or remain silent. If we assume that whistleblowers are rational actors, they will not submit a tip if the expected gains from doing so do not exceed the expected losses. The costs of blowing the whistle can be significant, including psychic discomfort, potential workplace retaliation, and industry blacklisting. ${ }^{90}$ The Dodd-Frank Act seeks to reduce these costs through the promise of confidentiality and retaliation protection but cannot eliminate them entirely. The benefits of blowing the whistle naturally include any gratification that comes from doing the right thing as well as the possible avoidance of complicity in wrongdoing and resulting liability exposure. The DoddFrank Act seeks to increase the benefits of reporting by adding a potential financial award to the list. ${ }^{91}$

A rational actor, in deciding whether the prospect of a whistleblower award tips the scales in favor of reporting, would calculate the expected value of that award (the product of the award's anticipated magnitude and probability). Next, she would discount the expected value to reflect both the time value of money (whistleblower awards can take years to receive ${ }^{92}$ ) and risk (assuming she is risk

89. See, e.g., Steven Shavell, Foundations of ECONOMic ANALYSis of LAW 579 (2004) (discussing the utilitarian function of state-paid rewards for reporting law violations). One might counter that whistleblowers deserve financial awards for their bravery in stepping forward; but there is no evidence that Congress meant to empower bureaucrats at the SEC to pay whistleblowers based on notions of moral desert, divorced from the incentive effects such awards would have on whistleblowers going forward. Another equally implausible notion is that a whistleblower has some sort of property right in the monetary recovery her tip helped to produce. Simply being aware of misconduct does not entitle one to a stake in the penalties or disgorgement the perpetrator of that misconduct may owe as a result, even if one incurred costs to learn of the information; turning that information over to the government does not magically create such a property interest. To be sure, the holder of the information in a sense "owns" the information that she acquired and, if not otherwise compelled by law, need not turn it over to government authorities. She will presumably do so only if she perceives it to be in her best interest. This, of course, takes us back to the incentive rationale for whistleblower awards.

90. See Marcla P. Miceli ET AL., Whistleblowing IN ORGanizations 101-30 (2008) (surveying studies on whistleblower retaliation).

91. With respect to some sorts of misconduct, the introduction of financial benefits for reporting may operate to reduce the perceived psychic benefits from doing so, potentially resulting in less whistleblowing activity. See Yuval Feldman \& Orly Lobel, The Incentives Matrix: The Comparative Effectiveness of Rewards, Liabilities, Duties, and Protections for Reporting Illegality, 88 TEX. L. REV. 1151, 1202 (2010). This phenomenon is unlikely to occur in the context of SEC whistleblowing, however. See Rose, supra note 14, at 1275-77 (explaining why).

92. Frustration over the delay recently led a whistleblower to initiate litigation against the SEC. See Rachel Graf, SEC Must Decide on Teva Whistleblower Award, D.C. Circ. Told, LAw360 
averse). The riskiness of an expected award is in part a function of the probability it will materialize (the tip might not produce a covered action or the SEC might find the whistleblower ineligible for an award). It is also a function of the certainty of the assumptions that underlie the calculation of the expected award. To calculate an expected award, a potential whistleblower must estimate several variables: the likelihood that a covered action will result from her tip, the likelihood that she will be determined eligible for an award, the likely amount of an eventual award, and the likelihood she will have to share it with others. The more uncertain the estimation of these variables, the more a risk-averse potential whistleblower will discount the expected value of the anticipated award when deciding whether blowing the whistle is worth the costs.

This is not to suggest that potential whistleblowers will actually sit down and do the math before deciding whether to come forward. But it is realistic to expect that they will consider, at a gut level at least, the harm that may come to them by reporting and compare it to the likely benefits. It is also realistic to expect that individuals who would be unwilling to come forward in the absence of the whistleblower award program - those whose minds the program seeks to change-will think about how big of an award they might get if they report, how likely the award is, how long they would have to wait for it, and how much risk they are willing to bear. They may not quantify the variables expressly and feed them into a formula, but they can be expected to consider them intuitively in reaching a decision. ${ }^{93}$

The SEC's Whistleblower Program seeks to encourage a greater number of tips by changing individuals' internal cost-benefit calculation as discussed above. But encouraging a greater number of tips is not an end in itself. Rather, it is designed to aid the SEC in its enforcement mission, which this Article assumes to be the deterrence of securities law violations. To be justified, a deterrence-focused enforcement regime must save more in social costs from deterred securities law violations than it produces in enforcement costs; an optimal deterrence regime

\footnotetext{
(May 1, 2019, 8:47 PM), https://www.law360.com/securities/articles/1154926 [https://perma.cc/M376-EABP].

93. An SEC choice not to pursue a tip eliminates any probability of an award, and it also might lessen the probability that a tipster will be discovered and therefore experience costs such as workplace retaliation or industry blacklisting. The cost side of the whistleblower's cost-benefit equation, in other words, could be dependent on a factor that is related to the probability of an award and hence the award's expected value. This would call for an even more sophisticated analysis than the one imagined in the text, and it is not realistic to expect even counseled whistleblowers to know how to model conditional expectations the way a mathematician would. That said, whistleblowers could very well appreciate that in the event their tip were not pursued, they would experience fewer costs, and this might lead them to find tipping worthwhile in more scenarios than the discussion above suggests.
} 
would minimize the sum of these costs. Whistleblower awards can work to reduce both variables. Private individuals often possess information about securities law violations that would be costly for the SEC to discover on its own; encouraging whistleblower tips can therefore help the SEC save on investigative costs it otherwise would have incurred. The lure of an award can also deter a greater number of violations than would otherwise be possible by increasing the likelihood that securities law violators will be caught. An individual contemplating a securities law violation would weigh the benefits of committing the violation against the costs of being caught, discounted by the likelihood of being caught. If the whistleblower program increases the likelihood of being caught, individuals will therefore find fewer violations worthwhile.

Betterment of the SEC's enforcement regime is not, however, the inevitable consequence of a whistleblower award program because the program itself creates costs. These include the cost of sorting through tips to determine which are worthy of pursuit, the cost of mistakenly pursuing tips that turn out not to be fruitful, as well as the cost of the award payments themselves-money that could be put to other socially valuable uses if not paid out to whistleblowers. To the extent the program encourages individuals to bypass or undermine a company's internal compliance system (often the most direct and effective way to identify and halt violations), that too produces costs that need to be taken into account. Depending on the nature and quantity of the tips elicited and the amounts paid out in awards, these costs could outweigh the benefits of the program. ${ }^{94}$

Whistleblower award programs like the SEC's therefore face a challenge: they need to encourage whistleblowers with desirable tips to come forward (namely, those that create more benefits than costs and thus push the SEC closer to its goal of optimal deterrence) without simultaneously encouraging the submission of undesirable tips (that is, those that create net costs and thus undermine the SEC's deterrence objective). ${ }^{95}$ Even if the SEC could costlessly identify and weed out tips

94. Weak tips could also have a deleterious ex ante effect on the behavior of would-be securities law violators. For example, if weak tips lead to erroneous liability, it could weaken market participants' incentive to comply with the law by decreasing the expected benefit of compliance relative to violation. See Yehonatan Givati, A Theory of Whistleblower Rewards, $45 \mathrm{~J}$. LEGAL STUD. 43, 45 (2016). Weak tips could also embolden would-be securities law violators by decreasing the probability of detection, if the SEC diverts resources that would otherwise be spent detecting misconduct to sorting through tips. Cf. Anthony J. Casey \& Anthony Niblett, Noise Reduction: The Screening Value of Qui Tam,91 WASH. U. L. REV. 1169, 1190-92 (2014).

95. Professor David Engstrom refers to this as the "Goldilocks Challenge." David Freeman Engstrom, Whither Whistleblowing? Bounty Regimes, Regulatory Context, and the Challenge of Optimal Design, 15 THEORETICAL INQUIRIES L. 605, 613 (2014); see also Casey \& Niblett, supra note 94 at 1196; Marsha J. Ferziger \& Daniel G. Currell, Snitching for Dollars: The Economics and Public Policy of Federal Civil Bounty Programs, U. ILL. L. REv. 1141, 1171-72 (1999). 
that are not worthy of pursuit, the program should strive to avoid award payouts that exceed what is necessary to achieve the desired incentives, given that those funds could be put to higher-valued social use.

It is difficult to define with greater precision which tips are "desirable" and which are not. Tip desirability is a continuum, and where along that continuum tips become more burdensome than helpful to the SEC will be a function, in part, of how efficiently the SEC can sort through tips and identify which are worthy of pursuit. It will also be a function of both the strength of the suspicion that underlies the tip and the nature of the misconduct the tip relates to. Oftentimes, whistleblowers are not certain that a securities law violation has occurred; instead, they suspect with a particular level of probability that a violation has occurred based on incomplete information. ${ }^{96}$ All else equal, tips based on higher-probability suspicions are more likely to produce deterrence benefits and less likely to produce wasted costs than tips based on relatively lower-probability suspicions, given that they are more likely to lead to the discovery of a securities law violation as opposed to innocent conduct. Tips that concern relatively more serious misconduct, again all else equal, are also more likely to lead to net deterrence benefits than those that concern relatively less serious misconduct, given that the social costs of the violations deterred as a result of such tips will be greater. Because the desirability of a tip is a function of both the probability it will unearth a violation and the level of social harm caused by the suspected violation, a relatively higherprobability tip concerning a relatively less serious violation might have the same desirability as a relatively lower-probability tip concerning a relatively more serious violation.

The SEC's covered action requirement operates to create differential incentives for individuals to report depending on tip desirability, thus understood. Recall that in order to be eligible for a whistleblower award, the Dodd-Frank Act requires that the tip lead to a "covered action," which means an SEC enforcement action resulting in the imposition of at least $\$ 1$ million in monetary penalties. This requirement discourages tips related to suspected misconduct that is not serious enough to warrant this level of punishment. Presumably, Congress believed that encouraging such tips would not produce sufficient deterrence benefits to outweigh the costs-that is, that such tips would be "undesirable."

The covered action requirement may also create differential incentives to report depending on how serious the suspected misconduct

96. Tips that are knowingly false are discouraged by the covered action requirement and by the requirement that tips be submitted under penalty of perjury. 
is, even when that misconduct would warrant at least $\$ 1$ million in monetary penalties. To see this, recall that a rational actor would calculate the expected value of a potential whistleblower award by multiplying its anticipated magnitude by its probability. To the extent that the SEC is more likely to pursue a case involving more serious misconduct, whistleblowers who suspect more serious misconduct will view a covered action as more probable than those who suspect less serious misconduct; thus, all else equal, they will be more likely to come forward because awards will have a higher expected value to them.

The covered action requirement likewise creates stronger incentives for individuals with higher-probability suspicions to come forward. This is because individuals with stronger suspicions will also view a covered action as more likely to result from their tip than potential whistleblowers with weaker suspicions. Thus, all else equal, potential awards will have a higher expected value in their eyes.

While the covered action requirement creates differential incentives to report based on tip desirability, it does not ensure that the whistleblower program will succeed in encouraging desirable tips without also encouraging undesirable tips. That will ultimately depend on the expected costs of whistleblowing relative to the amount of expected awards, and the latter depends not just on the award's probability but also on its anticipated magnitude. An award's magnitude will depend, of course, on the award calculation methodology.

Take an extreme but illustrative example: if every eligible whistleblower received an award of $\$ 1$ billion and typical whistleblowing costs were $\$ 100$, individuals with extremely low probability suspicions relating to even minor offenses would be encouraged to report, so long as the offense could conceivably warrant the imposition of at least $\$ 1$ million in sanctions. The deluge of tips would predictably move the SEC further from, not closer to, its goal of optimal deterrence by producing more in costs than deterrence benefits. ${ }^{97}$ Moreover, even if the SEC could costlessly identify and weed out those tips not worthy of pursuit, it would end up spending much

97. Even risk-averse individuals with low-probability tips would find it rational to come forward in this scenario, but the promise of this sort of jackpot might operate to change people's risk preferences. Individuals are often willing to make low cost wagers on small probability events with high payoffs, even when the expected payoff is less than the cost of the bet-thus displaying risk-seeking behavior. See Daniel Kahneman and Amos Tversky, Prospect Theory: An Analysis of Decision under Rish, 47 ECONOMETRICA 263 (1979); see also Thomas A. Garrett \& Russell S. Sobel, Gamblers Favor Skewness, Not Risk: Further Evidence from United States' Lottery Games, 63 ECON. LETTERS 85 (1999). Extremely large whistleblower awards relative to whistleblowing costs might trigger this "lottery mentality," leading to an even larger deluge of low probability tips than would be expected under our working assumption that whistleblowers are risk averse. 
more in award payouts than would be necessary to incentivize whistleblowers, thus wasting money that could be put to higher-valued social use. Conversely, if typical whistleblowing costs were $\$ 1$ billion and every whistleblower entitled to an award received only $\$ 100$, the program would not encourage anyone to come forward, including individuals with strong suspicions about misconduct that imposes significant costs on society.

The foregoing suggests some important factors to keep in mind when evaluating a whistleblower award calculation methodology. Most importantly, such a methodology should strive to produce award amounts that, on a discounted expected value basis, exceed the costs potential whistleblowers with desirable but not undesirable tips expect to bear. Even if the SEC could costlessly sort through tips, award amounts should not be set arbitrarily high because the funds in excess of what is needed to achieve the program's goals could be redeployed to more socially productive uses. This does not mean that the SEC should strive to set award amounts with complete precision, such that not one extra dollar is spent above what is necessary to create the right incentives for whistleblowers to report. Just as undesirable tips produce costs that detract from the efficiency gains of a whistleblower program, so too does the program's administration; thus, the costs associated with implementing an award calculation methodology is a factor to be considered. Finally, the ease of predicting award amounts using the methodology is also important. The higher the level of certainty with which a potential whistleblower can estimate an expected award, the smaller the risk discount they can be expected to apply, and hence the smaller the award needs to be to achieve the same incentive effect.

\section{B. Evaluating the Percentage Method}

Let us now evaluate the methodology currently used to calculate SEC whistleblower awards. As explained above, today such awards must be set at an amount not less than ten and not more than thirty percent of the monetary penalties collected in a covered action and any related actions, with adjustments between those extremes done on a percentage basis in light of the criteria set forth in Rule 21F-6.

One virtue of this methodology is that it is fairly simple to administer. Determining the ten percent minimum and thirty percent maximum award value requires a straightforward and elementary calculation. Determining where within this broad range the actual 
percentage awarded should fall requires SEC deliberation of the factors laid out in Rule $21 \mathrm{~F}-6$, but the SEC will be in possession of the facts necessary to assess each factor without the need for significant additional investigation. It can also weigh the factors however it chooses, without the risk of judicial second-guessing.

Another virtue of the percentage method is that it, like the covered action requirement, creates differential incentives for whistleblowers to come forward based on tip desirability. Whereas the covered action requirement achieves this through its impact on the probability of an award, the percentage method achieves this through its impact on award magnitude. To see this, consider first the DoddFrank Act requirement that awards equal between ten and thirty percent of monetary penalties collected. The penalty imposed on a defendant should be correlated to the seriousness of the violation being punished. All else equal, tying whistleblower awards to penalties imposed should therefore create stronger incentives for whistleblowers to come forward the more serious the misconduct suspected: expected awards will be higher and therefore more likely, when combined with any other benefits of reporting, to outweigh expected whistleblowing costs. 98

But to explain this logic is to reveal an important shortcoming of the percentage method as currently applied. The percentage method does not award whistleblowers a percentage of the value of the penalties imposed. It awards whistleblowers a percentage of the monetary penalties imposed that are subsequently collected. A correlation between this figure and the severity of the misconduct will likely exist,

98. I assume that whistleblower costs and the severity of the misconduct are exogenous to one another. If whistleblower costs rose in scale with the severity of the misconduct, the percentage method would not have the sorting effect described in the text. The relationship between whistleblower costs and the severity of the misconduct to which a tip relates is not easy to discern. The costs whistleblowers sometimes incur as a result of lost future employment opportunities might bear an inverse relationship to the severity of the misconduct. One might imagine that a whistleblower is less-not more-likely to be punished by potential future employers if it is known that the tip the whistleblower provided involved a severe securities law violation as opposed to a more technical violation that carries with it less social opprobrium. We tend, after all, to call individuals who report zoning infractions "snitches" and those who help identify murderers "heroes." For similar reasons, reporting on severe violations might produce less internal angst than reporting on other types of violations, meaning psychic costs may also bear an inverse relationship to the severity of the misconduct. There is a positive association, consistently observed in the empirical literature on whistleblowing, between the seriousness or magnitude of the wrongdoing and the level of whistleblowing activity, MTCELI ET AL., supra note 90, at 78; this is consistent with the idea that whistleblowing costs tend to be lower, rather than higher, when the wrongdoing is serious. But workplace retaliation, which itself can result in significant emotional harm, might be more likely the more severe the misconduct. Social scientists have theorized that the seriousness of the wrongdoing is one of several factors that may help predict workplace retaliation, a proposition that finds some (albeit less than universal) support in empirical studies. Id. at $101-30$. 
but it will be weaker than the correlation between the value of punishment imposed and the severity of the misconduct. How much the SEC collects in monetary penalties is, after all, not just a function of the size of the monetary penalty it chooses to impose, it is also a function of the defendant's ability to pay. (Even the SEC cannot squeeze blood out of a turnip.) The monetary penalties collected in an enforcement action against an individual, for example, will typically be substantially more limited than the monetary penalties collected in an enforcement action against a public company because of disparate solvency constraints. The SEC may impose severe nonmonetary penalties on defendants as a supplement to, or substitute for, monetary penalties, such as officer and director bars, referral to the Department of Justice for criminal prosecution, structural reforms, as well as other forms of injunctive relief. ${ }^{99}$ Although the SEC often stresses that nonmonetary remedies are critically important to its deterrence mission, ${ }^{100}$ nonmonetary relief is given no value in setting the Dodd-Frank Act's ten and thirty percent award boundaries.

By tying awards to money collected instead of the value of punishment imposed, the percentage method may bias the tip pool in a problematic way. Many commentators believe that the SEC should fine public companies less and pursue individual wrongdoers more. ${ }^{101}$ Cases

99. See Div. OF ENF'T, U.S. SEC. \& EXCH. COMM'N, 2018 ANNUAL REPORT 12-13 (2018), https://www.sec.gov/files/enforcement-annual-report-2018.pdf [hereinafter SEC 2018 ENFORCEMENT REPORT] (discussing non-monetary remedies).

100. See, e.g., id. at 13 ("One of the most important things that the Commission can do to protect investors is to remove bad actors from positions where they can engage in future wrongdoing."). The co-director of the SEC's enforcement division recently remarked:

[T] Division of Enforcement we think carefully about what of those tools to recommend to the Commission in every case. What we do not do is assess large penalties simply for the sake of counting them up at the end of the year. For that reason, the effectiveness of our program cannot be measured with resort to any one quantitative measure, but instead requires a nuanced and qualitative evaluation of our overall impact on achieving our investor and market integrity protection mission.

Steven Peikin, Co-Director, Div. of Enf't, U.S. Sec. \& Exch. Comm'n, Remedies and Relief in SEC Enforcement Actions, SEC (Oct. 3, 2018), https://www.sec.gov/news/speech/speech-peikin-100318 [https://perma.cc/R6JV-4A2G]. See also Stephanie Avakian, Co-Director, Div. of Enf't, U.S. Sec. \& Exch. Comm'n, Measuring the Impact of the SEC's Enforcement Program (Sept. 20, 2018), https://www.sec.gov/news/speech/speech-avakian-092018 [https://perma.cc/MUF3.CNGA] (arguing that statistics such as the dollar amount of judgements do not "provide a full and meaningful picture of the quality, nature, and effectiveness of the [Division of Enforcement's] efforts").

101. See, e.g., Jonathan R. Macey, The Distorting Incentives Facing the U.S. Securities and Exchange Commission, 33 HARV. J.L. \& PUB. POL'Y 639, 651-52 (2010) (critiquing the "SEC's tendency to resist prosecuting corporate executives and instead to pursue prompt settlements against corporate defendants"); James A. Kaplan, Why Corporate Fraud Is on the Rise, FoRBES (June 10, 2010, 6:00 PM), https://www.forbes.com/2010/06/10/corporate-fraud-executivecompensation-personal-finance-risk-list-2-10-kaplan.html\#7c6164e83aeb [https://perma.cc/3URT- 
against individual defendants, while recovering smaller dollar amounts, can have a far greater deterrence impact than cases against corporate defendants. Individual defendants are more likely to pay out of their own pocket, and they also face severe nonmonetary penalties. Pursuing individuals is harder than pursuing public companies, however - the agents that control the latter are often willing to settle and let the company's shareholders or insurance company bear the cost, whereas individuals facing real personal consequences are more likely to fight charges, requiring the SEC to bear its burden of proof. ${ }^{102}$ It is thus precisely with respect to these cases that whistleblower tips could be most impactful, by helping the SEC discover the evidence of personal misconduct that it will need to prevail. But if potential whistleblowers expect that their tip will provoke the SEC to pursue individual defendants rather than a deep-pocketed corporate defendant, they will be less likely to blow the whistle than if the opposite were true. The percentage methodology in this way sends a questionable signal to potential whistleblowers. It also reinforces any natural tendency the SEC has to favor suits against public companies because they are easier to resolve. ${ }^{103}$

The criteria that Rule 21F- 6 instructs the SEC to consider in setting the actual award percentage within the broad ten to thirty percent range also potentially operate to create differential incentives to report depending on tip desirability. These factors instruct, inter alia, that the more specific the information, the more important the tip in

QZYH] (arguing that the SEC should hold corporate executives and directors more accountable in order to deter corporate fraud); Zachary Kouwe, Judge Rejects Settlement Over Merrill Bonuses, N.Y. TIMES (Sept. 14, 2009), https://dealbook.nytimes.com/2009/09/14/judge-rejects-settlementover-merrill-bonuses/ [https://perma.cc/9FG7-UM3D] (noting the "long-standing criticism that the SEC has largely failed to prosecute cases against corporate executives, opting for quick settlements in which companies themselves are penalized instead of their leaders"); Gretchen Morgenson, Fining Bankers, Not Shareholders, for Banks' Misconduct, N.Y. TIMEs (Feb. 6, 2016), https://www.nytimes.com/2016/02/07/business/fining-bankers-not-shareholders-for-banks-

misconduct.html [https://perma.cc/X76M-2CT9] (arguing that fines levied on banking firms rather than executives have been ineffective).

102. See SEC 2018 ENFORCEMENT REPORT, supra note 99, at 14 ("individuals are more likely to litigate and the ensuing litigation is resource intensive"); Macey, supra note 101, at 646.

103. Both the False Claims Act and the IRS Whistleblower Program tie awards to monetary penalties collected. See discussion supra note 10 and accompanying text. But revenue-generation is an important goal in both of those contexts. False Claims Act suits seek to recover money that the federal government has wrongly been forced to pay out and IRS enforcement seeks to recover wrongly withheld tax revenue; favoring tips that promise to lead to the recovery of the most money for the federal government is thus sensible policy. The SEC's enforcement mission, by contrast, is not revenue-generation: it is to optimally deter securities law violations with the ultimate goal of protecting investors and our capital markets. This mission is not necessarily advanced by favoring tips that promise to lead to the highest collection of monetary penalties. $C f$. Ferziger \& Currell, supra note 95 , at $1182-83$ (observing similarly that agencies that are not primarily revenueseeking, such as the Customs Service, should not condition whistleblower bounty payments on monetary penalties collected). 
relation to the SEC's "programmatic interest in deterrence," and the more timely the tip, the larger the award percentage a whistleblower can expect. The whistleblower's participation in, or undermining of, the employer's internal compliance system is also a factor the SEC is instructed by the rule to consider in setting the award percentage. These factors reward tips that are more likely to produce net deterrence benefits.

The actual work the Rule $21 \mathrm{~F}-6$ criteria do to differentially incentivize desirable tips is questionable, however. Rule $21 \mathrm{~F}-6$ does not require that the SEC assign any particular weight to any particular factor, and its discretion to award percentages within the ten to thirty percent statutory range is judicially unreviewable. In its public award determination orders, the SEC has been very opaque about the effect it has given to the Rule 21F-6 criteria. Indeed, most of the time the SEC does not even publish the percentage awarded. ${ }^{104}$ This makes it difficult for potential whistleblowers to estimate their likely award percentage with any confidence, complicating the already difficult task of deciding whether tipping is worthwhile. Potential whistleblowers might conservatively assume that they will obtain the ten percent minimum award, or else account for the uncertainty surrounding a higher anticipated percentage by steeply discounting the expected award. Whistleblowers who retain counsel with experience representing successful claimants may be able to guess at a likely award percentage with greater confidence, but of course legal representation comes at a cost. The consequence is that potential whistleblowers will be more likely to find that the personal costs of coming forward exceed the benefits than would be the case if the SEC were more transparent about how it sets award percentages.

This points up another important weakness of the percentage method, both as adopted in the Dodd-Frank Act and as carried forward in Rule $21 \mathrm{~F}-6$. While the percentage method creates differential incentives to report based on tip desirability, it-like the covered action requirement-is essentially blind to whistleblowers' actual costs. ${ }^{105}$ If the penalties imposed in a covered action reflect its deterrence value,

104. See discussion supra note 70 and accompanying text.

105. Whistleblower costs are not obviously correlated with the monetary penalties collected in a covered action (see discussion supra note 98 and accompanying text), nor are they a factor that the SEC is required to consider in setting the award percentage. Rule $21 \mathrm{~F}-6$ lists "[a]ny unique hardships experienced by the whistleblower as a result of his or her reporting and assisting in the enforcement action" as one of six sub-factors that the SEC has the option to consider as part of its analysis of the degree of assistance provided by the whistleblower-itself one of seven plus/minus factors that the SEC may weigh however it likes in determining the award percentage. 17 C.F.R. $\S 240.21 \mathrm{~F}-6(\mathrm{a})(2)$ (vi) (2019). This is the only reference to whistleblower costs in the entirety of Rule 21F-6. 
then capping whistleblower awards at a fraction of monetary penalties collected ensures that an award will not exceed the deterrence value of the tip (ignoring enforcement and administrative costs). But the percentage method does not ensure that awards will not vastly exceed what is necessary to incentivize whistleblowers to come forward. Nor does it ensure that awards will not be so high as to encourage undesirable tips or, conversely, that they will be high enough so as to encourage desirable tips. This will all depend on the actual costs whistleblowers expect to bear by coming forward, which again the SEC does not currently take into consideration when setting award amounts. ${ }^{106}$

One could imagine an alternative award calculation methodology keyed to whistleblower costs rather than the penalty imposed. For example, whistleblowers whose tips resulted in a covered action could be guaranteed a set multiple of any costs they incurred from coming forward, with the multiple set to reflect the minimum probability of success the SEC wants the tips elicited to possess in the eyes of whistleblowers, with a kicker to offset risk aversion. ${ }^{107}$ The SEC

106. Cf. Robert Howse \& Ronald J. Daniels, Rewarding Whistleblowers: The Costs and Benefits of an Incentive-Based Compliance Strategy, in CORPORATE DECISION-MAKING IN CANADA 525, 536 (Ronald J. Daniels \& Randall Mork eds., 1995) (" $[1] \mathrm{t}$ is clear that using a percentage of the fines ultimately levied against the corporation as a basis for bounties paid to whistleblowers may cause payments to diverge systematically from the levels necessary to compensate whistleblowers for the risk of loss to their human capital from corporate retaliation.").

107. This cost-based methodology can be derived from a simple set of assumptions. First, potential whistleblowers will not report to the SEC if the expected benefits from doing so do not exceed the expected costs. Assume that a whistleblower award is the only benefit a whistleblower expects to receive from reporting and, for simplicity, ignore the time value of money and assume that whistleblowers expect to incur the same costs whether or not their tip results in a covered action. Under these circumstances, a potential whistleblower would not report unless the anticipated award payment, multiplied by its probability, exceeded the expected value of the whistleblower's costs. This condition can be expressed algebraically as $A^{\star} P_{A}>C$, where $A$ denotes the anticipated award payment, $\mathrm{P}_{\mathrm{A}}$ denotes the probability of the award, and $\mathrm{C}$ denotes the expected value of whistleblowing costs. Rearranged, this condition reveals that whistleblowers must anticipate an award that exceeds the expected value of their costs divided by the probability of an award: $A>C / P_{A}$. In other words, if a whistleblower has a ten percent probability of recovering an award, the anticipated award magnitude must exceed ten times the expected value of the whistleblower's costs for tipping to be potentially worthwhile. And if a whistleblower has a one percent probability of recovering an award, the anticipated award magnitude would need to be one hundred times higher than the expected value of the whistleblowers' costs to make tipping potentially sensible. If whistleblowers were risk neutral rational actors, the award amounts would need to exceed these figures by just a penny to induce reporting; in reality, they would need to be adjusted upward by an amount sufficient to offset the discount potential whistleblowers would apply as a result of risk aversion. Now, observe that the SEC could-and indeed should-decide the minimum probability of success it wants the tips the whistleblower program elicits to possess in the eyes of potential whistleblowers. Recall that if the program encourages too many undesirable tips, it can undermine the value of the program; the SEC is best positioned to figure out where to draw the line. Observe also that SEC is capable of identifying the award enhancement it thinks is necessary to offset risk aversion on the part of whistleblowers with tips of the desired strength. If the SEC made these determinations via rulemaking, in particular cases it could then 
could encourage tips with lower probabilities of success if they relate to more severe misconduct by applying different multipliers in cases involving different types of allegations (for example, a higher multiple could be promised to whistleblowers whose tips lead to the discovery of a scienter-based offense).

If implemented well, a cost-based method would more reliably incentivize reporting than does the percentage method. But it would be administratively more burdensome to apply and, importantly, it would encourage reporting even if the award payout would exceed the deterrence benefits produced by the tip. Just as the percentage method is disconnected from whistleblowing costs, the cost-based method is disconnected from the actual deterrence benefits achieved as a result of the tip. What is needed is a hybrid approach that takes both the deterrence value of the tip and whistleblower costs into account.

\section{IMPLICATIONS FOR REFORM}

The proposed revisions to Rule $21 \mathrm{~F}-6$ move precisely in this direction. The proposed revisions would allow the SEC, at least in a subset of cases, to consider the dollar amount of an award in order to determine whether the whistleblower award would be too small, or larger than necessary to reward the whistleblower and incentivize desirable tips in the future, and to adjust the award upward or downward if it so finds (within the statutory bounds). This would invite the SEC to focus on whistleblower costs, which are essentially ignored under the current methodology, within a percentage framework that is tied (albeit imperfectly) to the deterrence benefit produced by the tip. Such a hybrid approach is attractive from a theoretical perspective for the reasons outlined above. ${ }^{108}$

calculate whistleblower awards by calculating the costs the whistleblower incurred by coming forward, dividing it by the chosen probability of tip success, and multiplying the quotient by the rate of enhancement determined necessary to offset risk aversion. Assume, for example, that the SEC determines that it only wants tips from whistleblowers who believe they have at least a five percent probability of receiving an award, and that it estimates that a twenty percent enhancement is necessary to offset the typical level of risk aversion experienced by this sort of whistleblower. The SEC would then compute awards in individual cases by determining a value for the whistleblower's costs, denoted $\mathrm{C}$, and plugging it into the following formula: $A=(C$ $(.05)^{*} 1.20$. Simplified, this equation indicates that the SEC should award an amount equal to twenty-four times a whistleblower's costs. If this multiple were publicized, and if it were based on an accurate assessment of the discount that whistleblowers with tips of the desired strength would apply to an anticipated award based on risk aversion, rational actors who believe their tips have a five percent or greater probability of leading to an award would reliably be incentivized to report, and rational actors with weaker tips would not.

108. The hybrid percentage/dollar approach envisioned in the proposed rule resembles a common method used by courts in setting plaintiffs' attorneys' fees in class actions: courts calculate fees in the first instance as a percentage of the recovery, but compare the dollar value of the award 
It becomes unattractive only if we assume that the SEC will intentionally or inadvertently get the adjustments wrong, or will consume so many resources in making the adjustments that the change would produce more costs than benefits. The SEC could use the authority to make downward adjustments to eliminate unnecessary excess payouts to whistleblowers and to discourage undesirable tips, both laudable objectives; ${ }^{109}$ but downward adjustments could also discourage even desirable tips if they go too far. ${ }^{110}$ Is this is a significant concern?

The ability of the SEC to go "too far" is limited in the proposed rule. The SEC would only be authorized to make downward adjustments based on dollar amounts in cases likely to lead to the collection of $\$ 100$ million or more in monetary penalties, and the SEC could not adjust the award below $\$ 30$ million or ten percent of the collected monetary penalties, whichever is higher. Of course, there may be situations where a potential whistleblower would not find it rational to come forward unless he expected to be awarded more than $\$ 30$ million in the event a covered action resulted from his tip. But the potential impact of the rule will be limited to this subset, and the costs of administering the adjustment would be cabined concomitantly.

How would those falling within this subset be affected? Commissioner Jackson has suggested that these individuals would be deterred from reporting on the margins because the change would increase the uncertainty surrounding a potential whistleblower's expected award calculation, leading to a larger risk discount. ${ }^{111}$ The added uncertainty, he has observed, would include political uncertainty: even if whistleblowers trust the current SEC to use the discretion the proposed rule affords wisely, a future SEC may be hostile to the program. ${ }^{112}$

thus generated to an estimate of the attorneys' actual costs (a "lodestar") to check whether adjustment is warranted. See Theodore Eisenberg \& Geoffrey P. Miller, Attorney Fees and Expenses in Class Action Settlements: 1993-2008, 7 J. EMPIRICAL LEGAL STUD. 248, 267 (2010); Theodore Eisenberg et al., Attorneys' Fees in Class Actions: 2009-2013, 92 N.Y.U. L. REV. 937,945 (2017).

109. The potential for awards in excess of $\$ 30$ million to prompt undesirable tips is exacerbated due to the lottery mentality. Supra note 97 and accompanying text.

110. Upward adjustments, if too great, could also operate to encourage undesirable tips. Given that the objections to the proposed revisions to Rule $21 \mathrm{~F}-6$ focus on downward adjustments, I focus on downward adjustments in the text.

111. See Jackson, supra note 8:

[B]y increasing the uncertainty associated with the amounts of our awards, we decrease the value of those payments to whistleblowers at the moment when they decide whether to come forward-so we can expect that, under this proposal, fewer will come forward, and fewer frauds will be discovered in time to protect investors.

112. Id. 
A close examination of the reality of the program today suggests that Commissioner Jackson's concerns, while theoretically sound, may be practically unwarranted. As previously explained, it is monumentally difficult for a whistleblower to predict with any confidence the percentage they will be awarded within the ten to thirty percent range under existing practice. Not only is the SEC incredibly opaque concerning the weight it assigns to the various factors identified in the rule, ${ }^{113}$ it rarely ever discloses the percentage it has awarded. In those cases leading to whistleblower awards of $\$ 1$ million or more, the SEC has never revealed the percentage awarded. In light of this, it is likely that whistleblowers today already assume conservatively that they will receive only ten percent of monetary penalties collected. If this is the case, then the proposed rule revisions will not have the effect Commissioner Jackson fears, given that they would not permit adjustments below the ten percent statutory floor.

The proposed revisions might actually do more to alleviate uncertainty than exacerbate it. To see this, consider why it might be that the SEC behaves in such a nontransparent way in setting award percentages, despite the negative impact on the whistleblower program. Information about percentages would be much more helpful than information about the dollar amount of the awards, which the SEC does routinely publish, because dollar amounts are dependent on the monetary sanctions collected in a particular case (the details of which are almost always redacted); potential whistleblowers have no basis to assume that their tips will lead to comparable collections, and hence comparable awards. Publishing percentages along with the criteria that the SEC used to determine the percentages would be more helpful because it would allow whistleblowers to better predict the percentage they would be awarded, which they could then apply to the collections they anticipate in order to determine if blowing the whistle is worth the risk. There is no reason the SEC could not publish this information while still maintaining whistleblower confidentiality. Indeed, revealing dollar amounts is more likely to provide information that would allow someone to guess at a whistleblower's identity than would revealing percentages. So why does the SEC choose to report dollar amounts rather than percentages?

113. The IRS Whistleblower Program is much more transparent regarding the impact of plus/minus factors on the percentage awarded. See 26 C.F.R. $\$ 301.7623-4$ (2019) (explaining that vis-à-vis whistleblowers who provided substantial assistance, the IRS begins at fifteen percent, then considers positive factors, which can operate to increase the award to twenty-two or thirty percent; the IRS next considers the presence and significance of any negative factors, which may lead it to reduce a twenty-two percent award to eighteen percent, or reduce a thirty percent award to twenty-six percent or twenty-two percent). 
A cynic might suggest that those within the SEC responsible for determining award percentages enjoy their power to dole out (or withhold) significant sums of government money to whistleblowers without public scrutiny. Perhaps they use their discretion to richly reward their friends and punish their enemies - awarding the former the statutory maximum percentage and the latter the statutory minimum percentage. I doubt this is the case, ${ }^{114}$ but the public has no way of knowing for sure.

A less cynical, and in my view more plausible, explanation is that the SEC is already taking dollar amounts into account in setting awards because, well, it makes good sense to do so. My guess is that if the percentages were disclosed, we would observe an inverse relationship between the percentage awarded by the SEC to whistleblowers in a covered action and the monetary penalties collected, holding all else equal, with the percentages especially sensitive to dollar amounts when the awards are very small or very large (and thus particularly likely to be insufficient to induce reporting or, conversely, beyond what is necessary to induce reporting, given whistleblowers' costs). ${ }^{115}$ The SEC may keep the percentages it awards confidential in order to avoid criticism that it is not complying with Rule $21 \mathrm{~F}-6$, which as currently written does not permit consideration of the dollar value of the award. ${ }^{116}$ If this reading of the tea leaves is correct, the SEC might become more transparent regarding the percentages it is awarding, and why, if Rule $21 \mathrm{~F}-6$ is changed to permit the consideration of dollar amounts.

To be sure, revealing both the dollar amount and the percentage awarded in a particular covered action would jeopardize whistleblower

114. I believe that most individuals at the SEC are dedicated public servants with a high level of moral integrity. Moreover, there are several layers of internal review of award determinations within the SEC that should operate to constrain this sort of self-serving behavior, as well as the threat of Congressional oversight. See WP 2018 REPORT, supra note 20, at 14 ("Most award claim recommendations ... generally go through a multi-tiered, robust review process, including review and comment by Enforcement's Office Chief Counsel and the Commission's Office of General Counsel.").

115. Courts appear to behave in a similar way when awarding class counsel fees. Empirical studies reveal that courts award smaller percentages the higher the dollar value of a settlement. See Eisenberg \& Miller, supra note 108, at 263-65 (documenting the existence of a scaling effect, in which the fee percentage decreases as the class recovery increases); Eisenberg et al., supra note 108 , at $947-48$ (same).

116. It may be that the SEC is proposing these changes because it has faced criticism from award claimants contesting the percentage awarded them on precisely this ground. See, e.g., Order Determining Whistleblower Award Claim, Exchange Act Release No. 73174, at 3 n.4 (Sept. 22, 2014) https:/www.sec.gov/rules/other/2014/34-73174.pdf [https://perma.cc/686G-437J] (reporting that a $\$ 30$ million award claimant "suggested that a factor beyond those specified in Rule 21 F- 6 may have been considered" in setting the award percentage and complained that his "award is below the average percentage amount awarded to other successful claimants to date"). 
confidentiality because it would make it easy to identify the enforcement action to which the award relates. The SEC may believe that reporting high dollar awards does more to elicit press coverage of the program than would disclosing percentages alone, and that this, in turn, elicits more tips. But cheaper forms of advertising exist, and it is not clear that the publicity generated by media coverage of extremely large whistleblower awards is the type the SEC should seek to generate. Individuals with serious suspicions about wrongdoing are likely to visit the SEC's website and learn of the WP there. The tips elicited because of a news story reporting that the SEC awarded a whistleblower an eyepopping amount of money are more likely to come from individuals who have been swept up in a "lottery mentality": the tips elicited may be large in quantity, but are likely to be low in quality, potentially burdening the SEC more than they help. ${ }^{117}$ In any event, the SEC could reveal information about dollar amounts and percentages in a way that would not jeopardize whistleblower confidentiality. For example, the SEC could provide aggregated data about the dollar amounts of awards (for example, "Over the past year we have awarded over $\$ 100$ million to seven individuals"), or provide a vague description or general range of the dollar magnitude of the award along with the percentage in particular cases (for example, "Today we ordered a twenty percent award based on $\mathrm{X}, \mathrm{Y}$, and $\mathrm{Z}$ factors, which will yield a multi-million dollar payout").

For the foregoing reasons, I support the proposed revisions to Rule $21 \mathrm{~F}-6 .{ }^{118}$ But I also view them as incomplete. The analysis in the last Section reveals another glaring problem with the award calculation methodology that ought to be addressed: whistleblower awards should be tied to the value of the punishment imposed in the covered action resulting from the whistleblower's tip, rather than the amount of monetary penalties collected. This would better align a whistleblower's incentive to tip with what should be the SEC's enforcement prioritycatching the most egregious misconduct, not just the misconduct that is most likely to result in the collection of large monetary penalties. ${ }^{119}$

117. See supra note 97 and accompanying text.

118. Indeed, I might even support a rule change allowing the SEC to consider dollar amounts, within the statutory ten to thirty percent parameters, in all cases, not just those cases that fall at the extreme margin. But requiring the SEC to consider the incentive effects of the dollar value of awards in all cases would impose greater administrative costs on the agency, and it would create greater opportunities for distortion if the SEC exercised its adjustment power unwisely. The benefits of such a change might be worth it, but this presents a harder question-one I do not attempt to resolve here.

119. Derivative litigation provides an apt analogy: courts recognize that plaintiffs' attorneys can generate value for a company even when they reach non-monetary settlements, and thus require the corporation to pay attorneys' fees in such cases under the substantial benefit variant 
Congressional action would be required to untether the calculation of the ten percent floor and thirty percent ceiling from monetary penalties collected, but nothing in the Dodd-Frank Act prevents the SEC from adopting a rule that would allow it to consider the value of nonmonetary penalties in deciding what the award amount should be within the statutory bounds. Indeed, the existing Rule $21 \mathrm{~F}-6$ criteria are best read to permit the SEC to take this into account already. ${ }^{120}$ But the rule could and should be revised to require that the SEC do so explicitly and in every case.

This could be achieved by requiring the SEC to apply the percentage it otherwise determines appropriate using existing Rule $21 \mathrm{~F}-6$ criteria to the combined value of the monetary and nonmonetary penalties imposed in the case, in order to arrive at the ideal whistleblower award amount. ${ }^{21}$ The SEC would then be required to make payments to the whistleblower as monetary penalties are collected until that dollar target is hit, subject to the thirty percent statutory ceiling. This approach would require that the SEC assign a dollar value equivalent to nonmonetary penalties. This would be a difficult but worthwhile exercise. Not only would it improve the whistleblower program by tying anticipated awards more closely to the SEC's deterrence objectives, but it would also force the SEC to reflect deliberatively on the relative value of the various remedial tools available to it, perhaps leading to better enforcement choices. It might also benefit the SEC in its ongoing conversation with Congress regarding the proper lens through which to evaluate the SEC's enforcement program. The SEC has repeatedly urged Congress not to evaluate the effectiveness of its enforcement program by looking narrowly at quantitative measures like monetary penalties collected, emphasizing how important nonmonetary penalties can be in promoting deterrence. ${ }^{122}$ Congress might be more willing to heed this advice if the value of nonmonetary penalties could be expressed using a common, objective metric. If assigning a monetary equivalent to nonmonetary penalties were viewed as too difficult, however, a simpler

of the common fund rule. See Mark J. Loewenstein, Shareholder Derivative Litigation and Corporate Governance, 24 DEL. J. CORP. L. 1, 2 (1999).

120. One of the sub-factors that the SEC may consider when addressing the impact of the tip on its "programmatic interest in deterring violations of the securities laws" is "the degree to which an award encourages the submission of high quality information from whistleblowers by appropriately rewarding whistleblowers' submission of significant information and assistance, even in cases where the monetary sanctions available for collection are limited." 17 C.F.R. $\S 240.21 \mathrm{~F}-6$ (a)(3)(ii) (2019) (emphasis added).

121. This amount would be subject to adjustment if called for under the SEC's proposed revisions to Rule $21 \mathrm{~F}-6$.

122. See sources cited supra note 100 and accompanying text. 
alternative exists. Rule 21F-6 could be revised to require an upward adjustment of the award percentage in the event a covered action involved the imposition of substantial nonmonetary penalties. A whistleblower's entitlement to this upward adjustment, and its magnitude, should be clear and predictable.

More broadly, the SEC should be more transparent about the weight it assigns to the Rule $21 \mathrm{~F}-6$ criteria and about the actual percentages that it is awarding in covered actions. As noted above, this might occur naturally if Rule $21 \mathrm{~F}-6$ is revised to allow the SEC to consider dollar amounts in extreme cases, but to ensure greater transparency the SEC should be required to publish the percentage awarded to whistleblowers in every covered action as well to disclose in greater detail how and why it arrived at the percentage it did, albeit in a manner that would not jeopardize the whistleblower's confidentiality. ${ }^{123}$ By increasing the predictability of award percentages, this change would reduce the risk discount potential whistleblowers would otherwise apply to an expected award.

\section{CONCLUSION}

Any reform to the whistleblower award calculation methodology should be evaluated in terms of how well it advances the goals of the WP. This Article posits that the WP is designed to incentivize individuals to submit tips to the SEC that will advance the SEC's deterrence mission without simultaneously encouraging tips that will detract from that mission. The current percentage methodology for calculating whistleblower awards creates differential incentives to report based on tip desirability, but it fails to consider whether the award amounts produced by the methodology will actually be sufficient to elicit desirable tips or, conversely, will be higher than necessary to do so and possibly even so high as to encourage undesirable tips. That will depend on how the anticipated dollar amount of a potential award compares to the costs whistleblowers expect to bear by coming forward.

The proposed changes to Rule $21 \mathrm{~F}-6$ would remedy this shortcoming by allowing the SEC to consider the dollar amount of awards produced by the percentage method, at least in a subset of cases, and to make adjustments in light of the incentive effects. While the reform gives the SEC additional discretion in setting award amounts, it is not clear that the result will be increased uncertainty as Commissioner Jackson has warned; to the contrary, the reform may lead the SEC to be more transparent regarding how it determines 
award amounts than it is today. Under current practice, the SEC routinely discloses the dollar amount of awards but almost never discloses the percentage, an odd practice given that disclosing percentages would allow potential whistleblowers to anticipate their awards with greater certainty. If the SEC is withholding information about percentages to hide the fact that it is already taking dollar amounts into account in setting the award percentage, the reform will reduce this incentive for obfuscation.

While I support the SEC's proposed reforms to Rule 21F-6, the analysis in this Article suggests at least two more that should be considered. First, the SEC should be required to be more transparent about the percentages it is awarding and why. Increasing the predictability of award amounts will cause potential whistleblowers to apply a lower risk discount to their expected awards. Second, reforms that would better tie whistleblower awards to penalties imposed, as opposed to monetary penalties collected, should be considered. Such reforms would better align a whistleblower's incentive to tip with the SEC's deterrence mission and could produce collateral benefits for the agency. 


\section{APPENDIX A}

\section{Rule 21F-6. Criteria for determining amount of award.}

In exercising its discretion to determine the appropriate award percentage, the Commission may consider the following factors in relation to the unique facts and circumstances of each case, and may increase or decrease the award percentage based on its analysis of these factors. In the event that awards are determined for multiple whistleblowers in connection [sic] an action, these factors will be used to determine the relative allocation of awards among the whistleblowers.

(a) Factors that may increase the amount of a whistleblower's award. In determining whether to increase the amount of an award, the Commission will consider the following factors, which are not listed in order of importance.

(1) Significance of the information provided by the whistleblower. The Commission will assess the significance of the information provided by a whistleblower to the success of the Commission action or related action. In considering this factor, the Commission may take into account, among other things:

(i) The nature of the information provided by the whistleblower and how it related to the successful enforcement action, including whether the reliability and completeness of the information provided to the Commission by the whistleblower resulted in the conservation of Commission resources;

(ii) The degree to which the information provided by the whistleblower supported one or more successful claims brought in the Commission or related action.

(2) Assistance provided by the whistleblower. The Commission will assess the degree of assistance provided by the whistleblower and any legal representative of the whistleblower in the Commission action or related action. In considering this factor, the Commission may take into account, among other things:

(i) Whether the whistleblower provided ongoing, extensive, and timely cooperation and assistance by, for example, helping to explain complex transactions, interpreting key evidence, or identifying new and productive lines of inquiry;

(ii) The timeliness of the whistleblower's initial report to the Commission or to an internal compliance or reporting system of business organizations committing, or impacted by, the securities violations, where appropriate; 
(iii) The resources conserved as a result of the whistleblower's assistance;

(iv) Whether the whistleblower appropriately encouraged or authorized others to assist the staff of the Commission who might otherwise not have participated in the investigation or related action;

(v) The efforts undertaken by the whistleblower to remediate the harm caused by the violations, including assisting the authorities in the recovery of the fruits and instrumentalities of the violations; and

(vi) Any unique hardships experienced by the whistleblower as a result of his or her reporting and assisting in the enforcement action.

(3) Law enforcement interest. The Commission will assess its programmatic interest in deterring violations of the securities laws by making awards to whistleblowers who provide information that leads to the successful enforcement of such laws. In considering this factor, the Commission may take into account, among other things:

(i) The degree to which an award enhances the Commission's ability to enforce the Federal securities laws and protect investors; and

(ii) The degree to which an award encourages the submission of high quality information from whistleblowers by appropriately rewarding whistleblowers' submission of significant information and assistance, even in cases where the monetary sanctions available for collection are limited or potential monetary sanctions were reduced or eliminated by the Commission because an entity self-reported a securities violation following the whistleblower's related internal disclosure, report, or submission.

(iii) Whether the subject matter of the action is a Commission priority, whether the reported misconduct involves regulated entities or fiduciaries, whether the whistleblower exposed an industry-wide practice, the type and severity of the securities violations, the age and duration of misconduct, the number of violations, and the isolated, repetitive, or ongoing nature of the violations; and

(iv) The dangers to investors or others presented by the underlying violations involved in the enforcement action, including the amount of harm or potential harm caused by the underlying violations, the type of harm resulting from or 
threatened by the underlying violations, and the number of individuals or entities harmed.

(4) Participation in internal compliance systems. The Commission will assess whether, and the extent to which, the whistleblower and any legal representative of the whistleblower participated in internal compliance systems. In considering this factor, the Commission may take into account, among other things:

(i) Whether, and the extent to which, a whistleblower reported the possible securities violations through internal whistleblower, legal or compliance procedures before, or at the same time as, reporting them to the Commission; and

(ii) Whether, and the extent to which, a whistleblower assisted any internal investigation or inquiry concerning the reported securities violations.

(b) Factors that may decrease the amount of a whistleblower's award. In determining whether to decrease the amount of an award, the Commission will consider the following factors, which are not listed in order of importance.

(1) Culpability. The Commission will assess the culpability or involvement of the whistleblower in matters associated with the Commission's action or related actions. In considering this factor, the Commission may take into account, among other things:

(i) The whistleblower's role in the securities violations;

(ii) The whistleblower's education, training, experience, and position of responsibility at the time the violations occurred;

(iii) Whether the whistleblower acted with scienter, both generally and in relation to others who participated in the violations;

(iv) Whether the whistleblower financially benefitted from the violations;

(v) Whether the whistleblower is a recidivist;

(vi) The egregiousness of the underlying fraud committed by the whistleblower; and

(vii) Whether the whistleblower knowingly interfered with the Commission's investigation of the violations or related enforcement actions.

(2) Unreasonable reporting delay. The Commission will assess whether the whistleblower unreasonably delayed reporting the securities violations. In considering this factor, the Commission may take into account, among other things: 
(i) Whether the whistleblower was aware of the relevant facts but failed to take reasonable steps to report or prevent the violations from occurring or continuing;

(ii) Whether the whistleblower was aware of the relevant facts but only reported them after learning about a related inquiry, investigation, or enforcement action; and

(iii) Whether there was a legitimate reason for the whistleblower to delay reporting the violations.

(3) Interference with internal compliance and reporting systems. The Commission will assess, in cases where the whistleblower interacted with his or her entity's internal compliance or reporting system, whether the whistleblower undermined the integrity of such system. In considering this factor, the Commission will take into account whether there is evidence provided to the Commission that the whistleblower knowingly:

(i) Interfered with an entity's established legal, compliance, or audit procedures to prevent or delay detection of the reported securities violation;

(ii) Made any material false, fictitious, or fraudulent statements or representations that hindered an entity's efforts to detect, investigate, or remediate the reported securities violations; and

(iii) Provided any false writing or document knowing the writing or document contained any false, fictitious or fraudulent statements or entries that hindered an entity's efforts to detect, investigate, or remediate the reported securities violations. 
FIGURE 1: INDIVIDUAL AWARDS AS OF FISCAL YEAR 2018 (IN THOUSANDS)

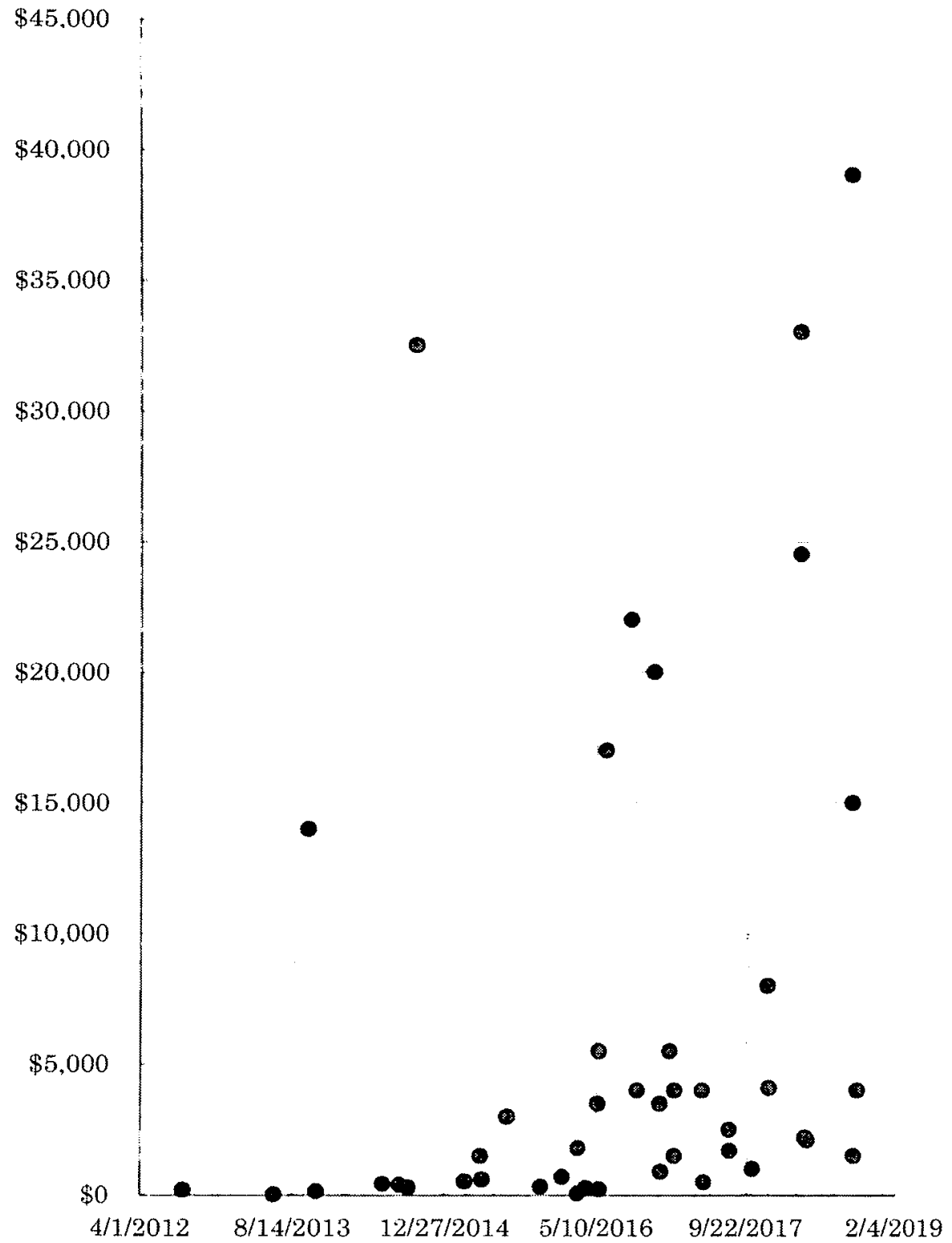

Data reflects the fifty-two individual awards announced by the SEC from the inception of the WP to the end of FY2018 with an estimated payout amount disclosed. When an estimated payout range was disclosed, the midpoint was used. 